\title{
MONETARY INTEGRATION AND THE COST OF BORROWING.
}

\author{
Marta Gómez-Puig* \\ Universitat de Barcelona and Barcelona Stock Exchange \\ First Version: November 2004 \\ Final Version: January 2006
}

\begin{abstract}
With European Monetary Union (EMU), there was an increase in the adjusted spreads of euro-area sovereign securities over Germany (corrected from the foreign exchange risk), causing a lower than expected fall in borrowing costs. The objective of this paper is to study the reasons for this increase, and in particular, whether the change in the price assigned by markets was due to domestic factors (credit risk and/or market liquidity) or to international risk factors. The empirical evidence suggests that it may have been a change in the market assessment of domestic (both liquidity and default risk) rather than international factors that caused the observed increase in adjusted spreads with Monetary Integration, even though, since market size scale economies have increased since EMU, their effect differs according to the size of the market.
\end{abstract}

JEL Classification Numbers: E44, F36, G15.

Keywords: Monetary integration, sovereign securities markets, international and domestic credit risk, and market liquidity.

\footnotetext{
Departament de Teoria Econòmica. Universitat de Barcelona. Diagonal 690, Barcelona 08034. Spain. T: 34-934.021.935. Fax: 34-934.039.082 E-mail: marta.gomezpuig@ub.edu.
} 


\section{Introduction.}

European Monetary Union (EMU) caused large-scale changes in euro-area sovereign securities markets (see Danthine et al. 2001, and the BIS Study group on fixed income markets, 2001). Before the introduction of the euro, yield differentials between European sovereign borrowers were mostly determined by four factors: expectations of exchange rate fluctuations, differences in domestic tax-regimes, differences in credit risk, and differences in market liquidity. The removal of foreign exchange risk in January 1999 and the elimination (or reduction to insignificant levels) of differences in tax treatment during the 1990s eliminated two of these factors, and paved the way for a much more integrated and competitive public debt market.

As a result, euro-area government bond markets began to be considered as a single market, comparable in terms of size to the US or Japanese markets. Nevertheless, segmentation did not disappear completely. In 2006, public debt management is still decentralised under the responsibility of 12 sovereign issuers with differences in rating and a variety of issuing techniques (see Favero, Missale and Piga, 1999). These are features that distinguish the euro-area debt market from its US and Japanese counterparts. One example of this segmentation is the persistence of yield differentials.

This paper sets out to examine this persistence and to explore what happened to euro-area countries' yield spreads on government bonds after the introduction of the euro. The pre-EMU literature speculated that with the elimination of currency risk, yield spreads would narrow and would primarily reflect default risk. Conversely, market participants and member state debt managers appeared to believe that EMU yield differentials would be due mostly to liquidity factors. Therefore, in order to reduce borrowing costs, debt managers introduced substantial innovations that were expected to enhance the liquidity of their bonds.

Actually, the main effects of the introduction of the euro in government bond markets were, on the one hand, an increase in the degree of substitutability among securities issued by different treasuries and higher levels of competition between issuers to attract investors, which led to a certain reorganisation of the market structure ${ }^{1}$, and on the other, a

\footnotetext{
${ }^{1}$ Blanco (2001) reports that on the side of the issuers, some significant changes were observed such as the harmonisation of market conventions in the computation of yields, the introduction of a single trading calendar and pre-announced auction calendars, or the increase in issue sizes. In some countries, the creation of large issues was facilitated by the introduction of programmes of exchange of old illiquid bonds for new bonds and by the concentration of issuance activity in a smaller number of benchmark securities. With the aim of attracting more investors, some of the smaller issuers such as Austria, Belgium, the Netherlands and Portugal resorted to syndication procedures. Others such as the French Treasury introduced new instruments such as constant maturity and inflation-indexed bonds.
} 
gain in the importance of credit risk and market liquidity in yield differentials. Before Monetary Union differences in these factors were perhaps not completely priced due to market segmentation.

Therefore, a first point that will be assessed in this paper is whether EMU has increased credit risk by denying governments the emergency exit of money creation and by forbidding both the ECB and the EU to bail out troubled governments; or whether, conversely, the maximum threshold that countries have for both their budget deficit and their level of public indebtedness (resulting in broad improvements in budgetary balances) and the possibility that markets do not regard the "no-bail-out" clause as credible, especially in the case of large markets (i.e. that the theory "too big to fail" holds), have actually resulted in a decrease in perceived credit risk.

Secondly, the introduction of the euro reduced segmentation among euro-area government bond markets. The removal of the exchange rate risk brought down an important barrier that had fostered captive domestic markets and had gone some way to explaining the home bias that existed in cross-border investments in the European Union. Adjaouté et al. (2000) traced the extent of the home bias, in both the bond and equities markets, for the major European countries -the UK, France, Germany, Spain, the Netherlands, and Italy -- during the period 1980-1999². The increased substitutability of sovereign securities after EMU intensified the rivalry between sovereign issuers to attract investors, since they were competing directly for the same pool of funding. In this new scenario, market liquidity differences may have become a more significant component of yield spreads. This is the second point that will be assessed in this study.

Nevertheless, as the literature on this topic is limited, the analysis will also build on findings in the empirical literature regarding sovereign bond yield spreads on emerging markets, which have suggested that spreads are also sensitive to international risk factors, mainly US risk factors and interest rates (see Codogno, Favero and Missale, 2003) 3.

\footnotetext{
2 They report that the United Kingdom held the highest share of foreign assets as a function of total financial wealth (24\%); Spain had the smallest (5\%), and the Netherlands, Germany and Italy had shares around 17\%. Moreover, as expected, for bills and bonds, the level of diversification was substantial only for banks in the UK, France and the Netherlands, i.e. the countries where intermediaries played an important role as market-makers in the eurobond markets. These results are consistent with Tesar and Werner (1995), who present evidence on long-term international investment patterns in Canada, Germany, Japan, the UK, and the US during the 1970-1990 period. At the beginning of the 1990s, the UK led this sample in international portfolio diversification, with foreign security holdings of $32 \%$ (compared with 10\% in Germany).
}

\footnotetext{
3 Our specification will be based on Codogno, Favero and Missale (2003), but with some important differences. First, the models do not control for the same variables. Second, their sample period for the daily estimation spans only 2002 (which is not included in the analysis presented in this paper). Third, their liquidity variables have been drawn from MTS, so they only correspond to the trading activity that takes place in that economic platform rather than in the whole of the euro-securities market. Consequently, the results are not really comparable.
} 
The analysis in this paper will then be threefold: first, we break down the European yield spreads into their two main domestic components (market liquidity and credit risk differences) which remained after the removal of currency risk. Second, we examine whether there was a change in the price assigned to them by markets after the introduction of the euro which might explain the yield spread behaviour observed. Third, we will examine the effects of international risk factors on yield differentials. The main goal of the analysis will be to identify the possible factors behind the observed average increase of 11.98 basis points in yield spreads during the first three years of Monetary Union, once they are corrected from the exchange rate factor (following Favero, Giavazzi and Spaventa (1997) we will correct pre-EMU spreads by estimating the foreign exchange factor as the differential between the 10 year swap rate in the currency of denomination of the bond and the 10 year swap rate in Deutsche marks)

The sample is composed of daily data from January 1996 to December 2001 (therefore, the same time interval - three years - will be considered for both pre-EMU and EMU periods) and includes all EMU countries except Luxembourg (whose public debt market is negligible), and Greece (which did not join Monetary Union until January 2001).

We will present the results of four different specifications" ${ }^{4}$ (I) a static panel regression, (II) a dynamic panel regression, (III) a static regression for each individual country, and (IV) a dynamic regression for every individual country, with the same explanatory variables in all four. The relative debt-to-GDP ratio will be used to identify differences in default risk, while two different variables will be used to capture market liquidity: the bid/ask spread (a proxy of market tightness) and on-the-run/off-the-run differentials (a complementary measure of market liquidity). Finally, the spread between 10year fixed interest rates on US swaps and the yield on 10-year Moody's Seasoned AAA US corporate bonds is introduced in the model as a proxy of international risk factors. To the best of our knowledge, no empirical analysis to date has used a daily dataset for two of the most important measures of liquidity, the bid/ask spreads and on-the run/off-the run yield differentials, corresponding to the trading activity in the whole of the euro-securities market.

The results of all the specifications are highly consistent, providing evidence that market size scale economies increased with Currency Union and that the rise was higher in smaller debt markets. A change in the market assessment of domestic (both liquidity and default risk) rather than international factors (which would play a smaller role) might be behind the observed increase in adjusted spreads with Monetary Integration, even though their effect varies according to

\footnotetext{
4 The results are consistent with those presented in Gómez-Puig (2005), even though different variables are used to capture domestic risk factors. In particular, in this new set of specifications, we will use the debt-to-GDP ratio instead of the rating differential as a proxy of credit risk. This change will not allow us to use the relative level of indebtedness as a proxy of market liquidity; otherwise, multicollinearity would pose a significant problem. This is the reason why both the bid/ask and the on-the-run/off-the-run spreads are the variables used to capture market liquidity.
} 
market size. Hence, the empirical evidence suggests that the removal of the exchange rate barrier has penalised small markets, not only because they are potentially more illiquid, but also because after EMU the "too big to fail" theory seems to hold: that is, the smaller the market, the higher the credibility of the "no-bail-out" rule. So, in the current context of increased competition between euro-area government securities markets, their relative success might be dependent on their size.

The rest of the paper is organised as follows: Section 2 explains the foreign exchange correction applied in the pre-EMU period. Section 3 outlines evidence concerning Monetary Integration in Europe and the evolution of the relative cost of borrowing. Section 4 focuses on the various domestic and international factors to which adjusted spreads might be sensitive, and describes the data. Section 5 explains the models and estimation methodology. Section 6 reports the results. Lastly, section 7 draws conclusions.

\section{Foreign exchange risk correction in the pre-EMU period.}

As discussed by Favero et al. (1997) a direct measure of the component of yield differentials not related to exchange rate factors can be obtained by comparing the yields of assets issued by two different states in two different currencies (say, one in Spanish pesetas, the other in D-marks) and the yield spreads in the same currencies and with the same life to maturity issued by the same (non-government) subject, or by two otherwise comparable issuers (in the second case, apart from the exchange rate risk, other factors influencing yield spreads can then be ignored when differences are taken). Candidates for this measure are: (1) long-term bonds issued by the same supra-national organisation (such as the World Bank or the European Investment Bank), (2) long-term bonds issued by the private sector, and (3) the fixed interest rates on swap contracts.

Giovannini and Piga (1994) study the differential between the interest rate on an Italian government bond issued in the Eurodollar market and a comparable World Bank bond issued in the global market. Alesina et al. (1992) compare interest rates on public and private financial instruments denominated in the same currencies in 12 OECD countries. And Favero, Giavazzi and Spaventa (1997), Arnold and Lemmen (2001), Blanco (2001) and Codogno, Favero and Missale (2003) compare government bond yield differentials and interest rate swap (IRS) differentials.

Supra-national issues are by definition free of any specific default risk. However, the market for bonds issued by supranational organisations is far less liquid and deep than that for government bonds. More importantly, supra-national 
issues in some currencies are intermittent. On the other hand, corporate bond yields display a relatively volatile cyclical behaviour and are not default risk-free. Interest rate swaps may also present problems, as they may be affected by the emergence of financial difficulties in the banking sector in a particular country (see Favero, Giavazzi and Spaventa, 1997).

However, on balance, the drawbacks of the interest differential on supranational issues or corporate issues seem to be greater. So even though it is not a perfect measure, the spread on fixed interest rate swap contracts can therefore be used as an indicator of the exchange rate determinant of the yield spread on government bonds, as it seems to be the best indicator of this yield spread component.

Since the early 1980s, interest rate swaps have become a popular vehicle used by many companies and financial institutions to hedge against interest rate risk. An interest rate swap is an agreement between two parties to exchange a series of interest payments without exchanging the underlying debt (which is denominated in the same currency), meaning that the default risk of the underlying asset is not translated into the level of the fixed interest rate on the swap contract. In a typical fixed/floating interest rate swap, the first party promises to pay the second at designated intervals a stipulated amount of interest calculated at a fixed rate on "the notional principal". The second party promises to pay the first at the same intervals a floating amount of interest on the notional principal calculated according to a floating-rate index 5 . IRS are liquidated by differences, "cash-flow netting". Essentially, then, an interest rate swap is a series of forward contracts on some reference interest rate, such as the Libor (see Bicksler and Chen, 1986).

The fixed rate is the one that is used to price the interest rate swaps ${ }^{6}$ IRS usually present a spread over the on-the run government bond yield at the same maturity, and their price basically accounts for the counterparty credit risk, the liquidity, the market risk of the swap contract, and the exchange-rate risk of the currency of denomination of the swap. Nevertheless, it can be assumed that the first three components cancel out when the differential between the 10-year

\footnotetext{
${ }^{5}$ In this paper, the 6-month money Libor rate (in the respective currency) before the EMU and the Euribor after its implementation.

${ }^{6}$ I.e. if a 10-year Spanish Peseta IRS is 11.50-11.60, this means that one should pay a fixed interest rate of $11.60 \%$ in exchange for the six-month Spanish Peseta Libor in the euro-market, or the six-month Libor in order to receive a fixed rate of $11.50 \%$.
} 
swap rate of one European country $i$ over, for example, Germany, is taken ${ }^{7}$. Hence, the swap rate differential is an appropriate measure for capturing the exchange-rate change component of yield spreads.

So we denominate:

$I_{i, 10}=10$-year Yield on sovereign bonds of country $i$

$\operatorname{IR} S_{i, 10}=10$-year Interest Rate Swap rate of currency $i$

Where, considering that differences in tax-regimes have been reduced to insignificant levels during the course of the 1990s:

$I_{i, 10}=f\left(\mathrm{DR}_{i, 10}, L_{i, 10}, E R_{i, 10}\right)$

$D R_{i, 10}=$ Default risk of country $i 10$-year sovereign bonds.

$L_{i, 10}=$ Liquidity of country $i 10$-year sovereign bonds.

$E R_{i, 10}=$ Exchange rate risk of currency $i$ over a 10 -year horizon.

Therefore the 10-year yield differential of country $i$ over Germany will be:

YIELD SPRE $A D_{i t}=\left[I_{i, 10}-I_{G E, 10}\right]_{t}=f\left(\left[\mathrm{DR}_{i, 10}-D R_{G E, 10}\right]_{t}\left[L_{i, 10}-L_{G E, 10}\right]_{t},\left[\mathrm{ER}_{i, 10}-E R_{G E, 10}\right]_{t}\right)$

Then, approximating:

$\left[\mathrm{IRS} S_{i, 10}-I R S_{G E, 10}\right]_{t}=\left[\mathrm{ER}_{i, 10}-\mathrm{ER}_{\mathrm{GE}, 10}\right]$

and building up the variable "ADJUSTED SPREAD," as the difference between the total yield differential and the swap rate differential,

\footnotetext{
${ }^{7}$ With regard to the counterparty credit risk, not only are most of the participants present in the different currency segments of the underlying swap market (the euro-deposit market) the same, but also the counterparty credit risk associated with swap rates is currently very low given the set of collateralisation and documentation standards recently developed by dealers and customers (see Liu, Longstaff and Mandell (2002), Duffie and Singleton (1997) and He (2000)). Secondly, market risk derives from the uncertainty associated with the floating leg of the swap contract (the six-month Libor rate). However, because market risk is usually highly correlated within euro-currency IRS contracts, it can also be ignored when differentials are taken. Finally, with respect to the liquidity of swaps contracts, it is reasonable to assume that, although they are currently very liquid (see BIS statistics), their liquidity will be highly correlated with that of the underlying government bonds. Therefore, it may vary within currencies. In this case, the estimated foreign exchange component (the swap rate differential) of total yield differentials would be biased upward and, consequently, the credit and liquidity component of government bonds would be biased downward. However, the data (see table 1) show an increase in the yield spread in the EMU period for countries in which the swap differential was not significant in the pre-EMU period. This is the case of Austria, Belgium, France and the Netherlands. This finding indicates that the aforementioned biases do not fully explain the rise in the price of liquidity and credit risk, when yield spreads are corrected for the foreign exchange factor and support the use of the swap rate differential as an appropriate measure for capturing the exchange-rate change component of yield spreads.
} 


$$
\begin{aligned}
\text { ADJUSTED SPREAD } D_{i t} & =A S P R E A D_{i t}= \\
= & {\left[I_{i, 10}-I_{G E, 10}\right]_{t}-\left[I R S_{i, 10}-I R S_{G E, 10}\right]_{t}=} \\
= & f\left(\left[D R_{i, 10}-D R_{G E, 10}\right]_{p}\left[L_{i, 10}-L_{G E, 10}\right]_{p}\left[E R_{i, 10}-E R_{G E, 10}\right]_{t}\right)-\left[E R_{i, 10}-E R_{G E, 10}\right]_{t}
\end{aligned}
$$

it can be inferred that the variable $A S P R E A D_{i t}$, which will be used as the dependent variable, will mainly account for credit risk and market liquidity differences ${ }^{8}$ of country $i$ sovereign securities over Germany. So, this variable could be considered an appropriate indicator of yield differential components not related to exchange rate factors.

\section{Monetary integration and the relative cost of borrowing: Some evidence.}

The aforementioned elimination of two of the main components of yield differentials prompted a substantial convergence in total yield differentials over 10-year German bond yields during the period January 1999-December 2001.

\section{[Insert Figure 1 and Tables $1 \mathrm{a}$ and $1 \mathrm{~b}$ about here]}

This is shown in figure 1 and table 1a: the average spread over German yields decreased from 58.22 to 25.24 basis points. Nevertheless, convergence only implied a sizeable reduction in the relative borrowing costs for the countries that presented wider spreads, lower rating and higher foreign exchange risk: that is, Italy, Spain, Portugal, and to a lesser extent Finland and Ireland. Conversely, the countries that took less advantage of the elimination of the exchange rate risk, Austria, Belgium, France, and the Netherlands, experienced an increase in their relative borrowing costs (15.34, 13.24, 11.08 and 16.92 basis points, on average, respectively, see table $1 \mathrm{~b})$. To sum up, while average gross yield spreads (relative to Germany) declined after EMU, they rose in 4 of the 9 countries.

\section{[Insert Figure 2 and Figure 3 about here]}

Moreover, what is really puzzling is that once adjusted for the swap differential (see figure 2), spreads rose for all 9 countries with Currency Union. The average value is 25.21 basis points in the EMU period compared with 13.23 basis points before EMU (see figure 3 and tables $1 \mathrm{a}$ and $1 \mathrm{~b}$ ). This clearly supports the idea that a change in either domestic (market liquidity or credit risk values) or international risk factors, or in their market pricing, might have occurred with

\footnotetext{
${ }^{8}$ We are not considering the effect of international risk factors in this breakdown.
} 
the euro, resulting in higher than expected borrowing costs. The main goal of this paper is to find an explanation for these rising yield spreads.

One possible explanation, which is supported by the beliefs of both market participants and member state debt managers, could be that in the actual context of increased competition between euro-area government securities markets their success might be limited by the extent of their liquidity and market size. Specifically, as the German sovereign debt market is the second largest in the euro-area (only surpassed by the Italian), a concentration of trading activity in the German market might have occurred and, consequently, wider liquidity differences vis-à-vis German bonds might have been translated into higher adjusted spreads 9

\section{[Insert Table 2 about here]}

More precisely, table 2 shows that while three countries, Italy, Germany, and France, represented 71.61\% of the euroarea market, four other countries, Austria, Finland, Portugal, and Ireland accounted for only 5.43\% of the total. Therefore, given (1) these large size differences observed between euro-area sovereign debt markets and (2) the fact that with the removal of the foreign exchange risk barrier captive domestic markets might have tended to decrease, it is likely that market size and liquidity differences within markets will have become more important.

Some literature supports the importance of market size in the success of a debt market. Martin and Rey (2004) show that in general size matters for asset trade, meaning that a larger country will benefit from higher asset prices than a smaller one, and point out that these market size effects are reminiscent of the home market effect in the new trade and geography literatures (Helpman and Krugman, 1985). As in the trade literature, these effects come from the combination of imperfect substitution and transaction costs. McCauley and Remolona (2000) note that if substantial fixed costs are involved in the production of information about the future path of interest rates, the size of the whole debt market matters. They calculate that there may be a size threshold around $\$ 100-200$ billions. Below this level, they state that sustaining a liquid government market may not be easy. In the euro-area, only five countries (Italy, Germany, France, Spain and Belgium) surpassed that threshold ${ }^{10}$. Economides and Siow (1988) point out that there may be a trade-off between liquidity and market size: the smaller the market, the lower the outstanding volume traded in it. Therefore, the more difficult it will be for investors to process and evaluate information about securities traded in that

\footnotetext{
${ }^{9}$ The existence of a very liquid futures bond market in Germany also represents an additional advantage of holding German bonds.

10 Austria, Finland, Greece, Ireland, and Portugal present an overall amount of public sector outstanding debt below the $\$ 100$ billion level, while The Netherlands entire amount of outstanding public debt is between $\$ 100$ and $\$ 200$ billions.
} 
market, and the higher the transaction costs and the liquidity premium. Moreover, if size matters for liquidity, "ex-ante" traders would prefer bigger and liquid markets (they will present lower price volatility, bigger scale economies and higher probability of a favourable match) to small and illiquid markets. Consequently, liquidity will be "self-reinforcing": since traders prefer to participate in liquid markets, more traders will participate in them, and more liquid they will be. This self-fulfilling nature of liquidity is also outlined by Plantin (2003) ${ }^{11}$.

On the other hand, in a scenario where EMU denies governments the emergency exit of money creation and forbids both the ECB and the EU to bail out troubled governments, another possible explanation for the observed rise in adjusted spreads could be a high degree of credibility for the "no-bail-out" clause. Consequently, it is vital to assess whether the too big to fail theory (TBTF), taken from the banking system ${ }^{12}$, might also hold in sovereign debt markets; if it does apply, the removal of the exchange rate barrier would have punished smaller countries twice, by making them pay both a higher liquidity and higher default risk premium than large ones. In this sense, in the banking system, as Kaufman (2002) points out, the TBTF theory states that adverse shocks from bank failures are perceived to be more strongly and widely felt (the existence of serious contagion and systemic risk makes regulators perceive that widespread devastation could result from a large bank failing) than similar shocks from the failure of non-bank firms of equal size, and the larger the bank, the more serious and widespread the damage. In the same vein, Goodhart and Huang (2005) develop a model of the lender of last resort from a Central Bank viewpoint. Consistent with the TBTF theory, their model suggests that the Central Bank will only rescue banks which are above a threshold size. Analogously, because adverse macroeconomic shocks and contagion consequences to neighbouring countries are much greater the larger the country's debt market, agents might expect that, beyond a certain threshold size, governments will receive financial support in case of fiscal distress in the form of a bail-out. Consequently, while big countries' default risk premium should not change (or may even decrease) with EMU, for small countries (whose public debt market does not reach the

\footnotetext{
11 The central intuition of his model is that liquidity is self-fulfilling because deals create positive externalities by increasing the depth of the secondary market, and thus the price of a future resale.

12 Too big to fail (TBTF) is a term frequently used in banking to describe how bank regulators may deal with severely financially troubled banks. The term came into common usage in 1984, when the regulators were faced with the economically insolvent Continental Illinois National in Chicago, which was both the seventh largest bank in the country at the time and the largest correspondent bank having interbank deposit and Fed funds relationships with more than 2,200 other banks. The federal regulators did not legally close the bank and protected all uninsured depositors and creditors against loss. In addition, at least initially, the old shareholders were not ousted. The Continental case was resolved in this way, in part, because the regulators believed that, particularly because of its large size and broad interconnections with other banks, allowing the bank and/or its parent bank holding company to fail and imposing losses on its uninsured depositors and creditors would have serious, adverse effects on other banks, financial markets, and the macroeconomy (see Kaufman, 2002).
} 
threshold size), agents might expect the "no-bail-out" rule to hold. So, their default risk should increase with their membership of Monetary Union, since they lose monetary authority.

\section{Domestic and international risk factors explaining adjusted yield spreads.}

Now that we have defined the dependent variable $\left(A S P R E A D_{i}\right)$ which allows separation of the liquidity and credit risk components from expected exchange-rate depreciation, a decomposition between the liquidity premium and the creditrisk component is attempted by modelling their behaviour to a number of factors that potentially affect only one of them.

With regard to domestic risk factors, a crucial issue in this paper (and one that is vital for policymaking) is the identification of the two main domestic sources of risk that have composed yield spreads since the start of Monetary Integration: (1) differences in credit risk and (2) differences in market liquidity. With this goal in mind the relative debtto-GDP ratio will be used as a proxy to measure differences in credit risk. This variable has been widely used in the literature by other authors (Bayoumi, Goldstein and Woglom (1995) among them) ${ }^{13}$ and presents the advantage over other measures such as the rating differential that it cannot be considered an ex-post measure of fiscal sustainability.

Because market liquidity is an elusive concept, we use the definition provided by the Bank for International Settlements (1999): “a liquid market as a market where participants can rapidly execute a large volume of transactions with a small impact on prices ${ }^{14}$ ". In this paper, two different proxy variables will be used to measure this effect: (i) the bid/ask spread, and (ii) the on-the run/off-the run spread.

\footnotetext{
13 In particular, these authors find support for the market discipline hypothesis in the U.S. bond markets. This hypothesis assumes that yields rise smoothly at an increasing rate with the level of borrowing. However, if these incentives prove ineffective, credit markets will eventually respond by denying irresponsible borrowers further access to credit. Nevertheless, the model presented in this paper and Bayoumi et al. model do not control for the same variables and cannot be compared.

${ }^{14}$ Likewise, they point out that the usual approach is to consider market liquidity according to at least one of three possible dimensions: tightness, depth and resiliency. Tightness is how far transaction prices diverge from mid-market prices, and can generally be measured by the bid/ask spread. Depth denotes either the volume of trades possible without affecting prevailing market prices, or the amount of orders on the order books of market makers at a given time. Resiliency refers to the speed with which price fluctuations resulting from trades are dissipated, or the speed with which imbalances in order flows are adjusted. However, other measures, though they do not directly coincide with these three dimensions, are often regarded as readily observable proxies of market liquidity: the number and volume of trades, trade frequency, turnover ratio, price volatility, the number of market participants, the yield spread between the "on the run" and the "off the run" issues, the outstanding volume of a specific security, or the overall outstanding volume of securities traded in one market, among others.
} 


\section{(i) The bid/ask spread.}

This variable is often used as a measure of liquidity because it reflects the cost incurred by a typical investor in unwinding an asset position and measures one of the most important dimensions of liquidity: tightness, i.e. how far transaction prices differ from mid-market prices. Additionally, the liquidity of an asset is generally understood as the ease of its conversion into money. Therefore, because the conversion of an asset into money involves certain costs (searching costs, delays, broker's commissions, etc...), the higher these costs, the lower the degree of liquidity. Note that as market dealers reduce their liquidity risk, the bid/ask spread should narrow with trading activity.

\section{(ii) The on-the run/off-the run spread.}

The yield spread between more and less liquid securities is also a liquidity measure used in the Treasury market (see Fleming, 2003). Since liquidity has value, more liquid securities tend to have higher prices (lower yields) than less liquid securities. The yield spread is often calculated as the difference between the yield of an off-the-run (older securities of a given maturity) and that of an on-the-run (benchmark) security with similar cash-flow characteristics. Positive spreads indicate that on-the-run securities are trading at a yield discount (or price premium) to off-the-run securities. This spread provides an insight into the value of liquidity not provided by other measures like the bid/ask spread. The fact that both measures of liquidity are so different ${ }^{15}$ is the reason why their correlation coefficient is not significant. On the other hand, the correlation coefficient between these liquidity variables and the credit risk proxy (the relative debt-to-GDP ratio) is not significant either. Therefore, we can assume that the estimation results will not suffer from multicollinearity problems ${ }^{16}$.

To sum up, the two variables described will be used in our models to control for market liquidity. However, for the sake of fairness, it has to be noted that measuring the liquidity premium remains a difficult issue because market liquidity and credit risk interact with each other. The lack of liquidity increases the effect of risk. This is because liquidity variables, such as the bid-ask spread, reflect the risk borne by market makers in managing unbalanced positions. As credit risk increases, so does the risk they face. A (credit-related) flight-to-quality argument might also be used to

\footnotetext{
$15 \mathrm{Bid} /$ ask spreads series used in this paper are only related to the "on-the-run" issues and show the differential between the bid and ask quotations for the "benchmark" or "on-the-run" issue at every moment of time.

16 Conversely, multicollinearity would appear if we estimated a model with the proxy of market liquidity used in Gómez-Puig (2005) -the relative level of indebtedness- together with the relative debt-to-GDP ratio because these two variables present a high correlation coefficient indeed.
} 
interpret the significance of the on-the-run/off-the-run differentials ${ }^{17}$. In these circumstances, the results presented in this paper turn out to be highly consistent; they indicate that, since EMU, the market assessment of both liquidity and credit risk factors has been closely related inside countries, as it depends on the size of their debt market.

Lastly, a third point that will be assessed in this paper is the relevance of international risk factors on yield spreads. Hence, the analysis will also build on the findings of some recent work according to which yields spreads on eurozone government securities are sensitive to international risk factors ${ }^{18}$.

As defined in section 2, the dependent variable is $A S P R E A D_{i t}$, i.e. the difference between the total yield differential of 10-year government bonds and the 10-year interest rate swap differential. The sample comprises daily data spanning the period January 1, 1996 to December 31, 2001. Yields and swap rates are obtained from Datastream and correspond to the "on the run" (benchmark) 10-year issue for each market at every moment of time. They are quoted rates at market close.

\section{[Insert Table 3 about here]}

Datastream creates continuous yield series by taking the yield from the current benchmark in each market and using it to update a separate time series. As a benchmark changes, data are taken from a new stock on the first day of the month. Table 3 presents the starting benchmark dates used by Datastream as well as the characteristics of the different benchmarks that compose the yield and swap series.

With regard to the bid/ask spreads series, daily time-series have been created by calculating the spread between the bid and ask quotations provided by Bloomberg for the "on the run" (benchmark) 10-year issue for each market at every moment of time, using the same benchmarks and starting dates that Datastream uses to create the 10-year yields and swap rates series (see table 3). For all the different issues Bloomberg provides daily quoted prices calculated as the average bid and ask quotations at the close.

A similar methodology was used to build the on-the-run/off-the-run spread daily time-series. These series were created by calculating the differences between the "on the run" (benchmark) 10-year issue and the "off the run" (immediately

\footnotetext{
17 See Vayanos (2004) among others.

18 See Codogno, Favero and Missale (2003) or Bernoth et al. (2004) among others.
} 
older security) 10-year issue yields provided by Bloomberg for each market at every moment of time, also using the same benchmarks and starting dates that Datastream uses to create the 10-year yields and swap rates series (see table 3).

The overall outstanding amounts of public debt data have been drawn from the Bank for International Settlements (BIS; see table 2) and the GDP from Eurostat (in the case of Ireland, the Central Statistics Office). However, as these series are only provided with quarterly frequency, for the construction of the relative debt-to-GDP ratio daily timeseries, the rest of the data have been extrapolated assuming a daily constant rate of increase of those volumes, which in fact present very slight differences within countries over the studied period. For this reason, it can be assumed that the extrapolation will not produce important biases in the data and can be applied in this case.

And finally, the spread between 10-year fixed interest rates on US swaps and the yield on 10-year Moody's Seasoned AAA US corporate bonds (USSPREAD $D_{i t}$, has been calculated from daily data obtained from Datastream.

All the variables included in the estimation that capture domestic risk factors are in relative terms to the German ones, as our dependent variable $\left(A S P R E A D_{i t}\right)$ is the difference between the total yield differential and the swap differential of country $i$ over Germany. Therefore, $B I D A S K D I F_{i t}$ is the difference between the bid/ask spread in country $i$ and the $\mathrm{bid} /$ ask spread in Germany, ONOFFDIF ${ }_{i t}$ is the difference between the on the run /off the run spread in country $i$ and that in Germany, and LNDEBTGDP $i t$ is the (log) deviation of country $i$ debt-to-GDP ratio from Germany's debt-toGDP ratio.

\section{Modelling adjusted yield spread behaviour.}

\subsection{Panel models with both domestic and international factors.}

The first and second specifications will be panel regressions that include nine groups or countries. In these specifications, in addition to the variables already mentioned in the introduction (LNDEBTGDP $P_{i t}$ BIDASKDIF $_{i \hbar \text {, }}$

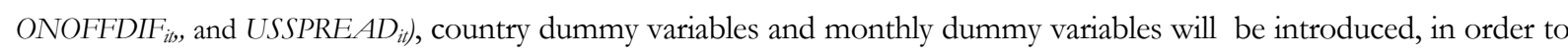
capture the potential existence of both specific features via country and temporal effects. Besides, as the goal is to analyse if the marginal effect of the different variables changed with EMU, a dummy (DPRE), that takes the value 1 in the pre-EMU period (and 0, otherwise), will also be introduced and the coefficients of the interactions between this dummy and the rest of variables will be calculated. Finally, in order to assess if there exists a varying relationship between liquidity variables and the yield $A S P R E A D S_{i t}$ (if liquidity is self-fulfilling, the proxies of market liquidity might 
present a non-linear relationship, i.e. a liquid/illiquid market might lead to an increasingly lower/higher liquidity premium) a quadratic specification for the variables $B I D A S K D I F_{i p}$ and $O N O F F D I F_{i t}$ will be formulated. So, with the following defined previously:

$B I D A S K D I F 2_{i t}=(B I D A S K D I F)^{2}{ }_{i t}$

ONOFFDIF ${ }_{i t}=(\mathrm{ONOFFDIF})_{i t}^{2}$

The domestic risk variables $\left(D R V_{i t}\right)$ will be:

$D R V_{i t}=\left(L_{N D E B T G D P} i t\right.$ BID ASKDIF $i t, B I D A S K D I F 2_{i,}$ ONOFFDIF $_{i b}$ ONOFFDIF $\left._{i t}\right)$

While the international risk variables $\left(\operatorname{IRV} V_{i t}\right)$ will be:

$I R V_{i t}=U S S P R E A D_{i t}$

The international risk variable that allows adjusted spreads to be explained in terms of exogenous risk premiums (specifically, banking risk premiums in the United States) will appear in the regression both linearly, and interacting with the domestic risk variables. This captures the idea that international risk affects adjusted yield differentials because Eurozone government bonds are imperfect substitutes due to differences in either market liquidity or default risk. Therefore, the interaction term identifies changes in adjusted spreads that can be entirely attributed to domestic risk differentials. However, the linear term is also necessary, as international factors might affect the adjusted yield spread either because of "structural" differences in market liquidity or differences in non-varying unobservable fundamentals, such as the reputation of the issuing governments. Hence, the independent effect of domestic risk variables on adjusted spreads is also controlled by entering these variables linearly in the regressions.

\section{STATIC PANEL MODEL}

Therefore, the first panel model with both domestic and international risk variables will be: $y_{i t}=\alpha_{i}+\beta X_{i t}+\gamma D P R E_{i t}+\delta M O N T H L Y D U M M I E S_{t}+\lambda C O U N T R Y D U M M I E S_{i}+\varepsilon_{i t}$

where, with the international $\left(\operatorname{IRV} V_{i t}\right)$ and domestic risk variables $\left(D R V_{i \hbar}\right)$ previously defined, the vector of independent variables will be:

$X_{i t}=\left(I R V_{i p} D R V_{i p} D R V_{i t}^{*} I R V_{i t}\right)$ 


\section{DYNAMIC PANEL MODEL}

In the second estimated model, taking into account that some aspects of both credit risk and market liquidity do not change over the considered period, the objective will be to identify the relative importance of liquidity and default premiums in explaining fluctuations, rather than levels of yield differentials. With this aim a lag of the dependent variable will be introduced in the model, which will allow for a slow dynamic adjustment to a long-term equilibrium value of the variable $A S P R E A D_{i t}$

So, we will estimate the same model as in specification I:

$y_{i t}=\alpha_{i}+\beta X_{i t}+\gamma$ DPRE $_{i t}+\delta M O N T H L Y D U M M I E S_{t}+\lambda$ COUNTRYDUMMIE $_{i}+\varepsilon_{i t}$

including a lag of the dependent variable in the vector of independent variables:

$X_{i t}=\left(y_{i t-1}, I R V_{i t} D R V_{i p} D R V_{i t}^{*} I R V_{i t}\right)$

In addition,

$\beta=\beta_{1}+\beta_{2} \mathrm{DPRE}_{i t}$

We honestly think that a formal coefficient test $\mathrm{H}_{0}: \beta_{1}=\beta_{1}+\beta_{2}$, in order to assess whether the impact of independent variables on the adjusted interest differential changed significantly with the start of EMU, is not necessary as long as $\beta_{2}$ turns out to be significant. Therefore, for both models I and II; the marginal effect of a variable will be:

$\beta=\beta_{1}$ (in the EMU period), and

$\beta=\beta_{1}+\beta_{2}($ pre-EMU)

\subsection{Regressions for every individual country.}

In the two panel regressions above, all country dummies (with the exception of those of Ireland and Finland) turn out to be significant at the 5 percent confidence level, meaning that specific factors in each different country are relevant and suggesting that a separate estimation for each of them will provide wider information. We will do this in the third and fourth sets of regressions where, using the same independent variables as in the panel regressions I and II, both static and dynamic estimations will be implemented separately for each nine euro countries that are included in the sample. 
Therefore, the following empirical model on daily data will be implemented separately for each individual country:

$y_{i t}=\alpha_{i}+\beta X_{i t}+\gamma D P R E_{i t}+\varepsilon_{i t}$

Hence, two sets of regressions (III and IV) will be calculated using the same estimation equations as in section 5.1.

\section{Results.}

The estimation methods used in all specifications, Feasible Generalized Least Squares (FGLS) in panel estimations and a regression with Newey-West standard errors in the estimations for each euro-country, are robust to the possible existence of autocorrelation and heteroscedasticity in the error terms.

The results of all four specifications are highly consistent and provide evidence that market size scale economies have increased with Currency Union and that this increase is higher the smaller the debt market. A change in the market assessment of domestic risk factors (both liquidity and credit risk) rather than international factors might be behind the observed increase in adjusted spreads with Monetary Integration, even though the effect differs according to the size of the market.

Tables 4 to 7 present respectively the values and standard errors of the estimated coefficients corresponding to the first, second, third, and fourth specifications. For each exogenous variable, these tables allow calculation of the corresponding marginal effects for the EMU period $\left(\beta_{1}\right)$ and the pre-EMU $\left(\beta_{1}+\beta_{2}\right)$, from the estimated coefficient values.

\section{[Insert Tables 4 and 5 about here]}

Tables 4 and 5 present the results from the panel regressions (static and dynamic) that correspond to models I and II. Apart from the fact that in the dynamic model the lag of the dependent variable is significant (even though its marginal effect over aspreads decreases with EMU) the results from both specifications present only slight differences. They show an increase in the marginal impact of market liquidity's variables since Monetary Union. Both linear terms of the on-the-run/off-the-run and the bid/ask spread increase with the euro. On the other hand, when it is interacted with the international risk variable (which, though significant in both specifications, only experiences an increase in its marginal effect with the euro in the static model), the behaviour of the on-the-run/off-the-run variable is non-linear, suggesting that liquidity is self-fulfilling. Moreover, its marginal impact also rises with EMU. With regard to the default risk variable 
behaviour, tables 4 and 5 show that its significance has increased since the beginning of the EMU (which would support a high degree of credibility for the "no-bail-out" rule).

\section{[Insert Table 6 and Table 7 about here]}

The country-specific estimations (see tables 6 and 7 corresponding to models III and IV) suggest a substantial decrease in the significance of the lag dependent variable (which captures the structural aspects of both credit risk and market liquidity) in the EMU period (table 7), except in countries that present a high debt-to-GDP ratio relative to Germany. Actually, the effect decreases in the case of Finland, France, the Netherlands and Portugal, remains unchanged in the case of Austria, and rises for Ireland, Italy, Belgium, and Spain. Therefore, with Currency Union, adjusted spreads are, in general, less sensitive to structural differences in market liquidity or credit risk, except in the countries where debt sustainability is more likely to be a problem ${ }^{19}$. This is the most important result obtained from the dynamic model; in general, the static specification (see table 6) seems to bring more information because the significance of the majority of the variables decreases when a lag of the dependent variable is included in the estimation.

Table 6 presents very interesting results. First, the variation in the marginal impact of the default risk variable in the EMU period differs according to the size of the market. Therefore, while in small markets the marginal effect increases (as in the Netherlands) or remains positive in spite of falling (as in Austria and Finland), in larger and more indebted countries $^{20}$ the impact either remains negative (as in Belgium) or becomes negative (as in Italy, Spain and Portugal). This clearly supports the idea that the FBTF theory holds in sovereign debt markets, since it reinforces the relevance of market size in the degree of explanatory power of credit risk variables. In addition, the majority of the countries that present an increase in the marginal effect of one of the market liquidity proxies in the EMU period have either very small or very large government debt markets. For instance, with EMU, the non-linear behaviour of one of the market liquidity variables included in the model (the on-the-run/off-the-run spreads) is particularly notable in two of the smallest (Austria and Finland) and two of the largest markets (France and Spain). Analogously, for the smallest and the biggest debt markets (Ireland and Italy, respectively) the non-linear term of the bid/ask spread rises since EMU. This non-linear behaviour of market liquidity variables (if they increase/decrease, liquidity premium rises/drops at an

\footnotetext{
19 This is clearly not the case of Ireland. However, the results obtained for this country should be interpreted with caution because the number of available observations is substantially smaller than for the other countries.

${ }^{20}$ During the period 1996-2001, on average, the three countries with the larger ratio debt-to-GDP were: Belgium (102.49\%), Italy (95.36\%) and Spain $(48.82 \%)$.
} 
increasing rate), especially in small and large debt markets, supports the idea that liquidity is self-fulfilling. So as Economides and Siow (1988) point out, since traders prefer to participate in liquid markets, their transactions will flee from illiquid to more liquid markets, fostering a liquidity trade-off from the small to larger debt markets. On the other hand, the international risk variable marginal impact (unlike panel regressions I and II) in the few cases where it is significant becomes negative with the euro. Therefore, the adjusted spread increase with Currency Union may be due to domestic risk factors rather than to international ones. However, when the variable that captures international risk is interacted with the linear term of some market liquidity proxies the marginal impact over adjusted spreads registers a change in the EMU period for some small markets: for instance, when it is interacted with the on-the-run/off-the-run spread, the marginal effect increases once again in Austria and Finland (two of the smallest debt markets in the EMU). To conclude, in both specifications (static and dynamic) the constant (which should capture other factors affecting adjusted yield spread fluctuations) is always significant except in the case of France and Ireland.

\section{Conclusions}

Euro-area countries' adjusted spreads over 10-yr German securities experienced an average rise of 11.98 basis points in the first three years of Monetary Union. This resulted in a lower than expected decrease in the costs of borrowing (which actually increased in the case of Austria, Belgium, France and the Netherlands). Therefore, changes either in domestic risk factors (market liquidity and/or credit risk), in international risk factors or in their market pricing may have occurred with EMU.

The results of all specifications are highly consistent; they provide evidence that market size scale economies seem to have increased with Currency Union and that the smaller the debt market, the higher the rise. Specifically, a change in the market assessment of domestic (both liquidity and default risk) rather than international factors (which would only play a smaller role) might be behind the increase observed in adjusted spreads with Monetary Integration, even though the effect differs according to the size of the market ${ }^{21}$. Therefore, the removal of the exchange rate barrier seems to have punished smaller countries twice (they are forced to compete in terms of liquidity with larger countries for the same pool of funding, only being able to offer smaller bond issues), by making them pay both higher liquidity and a higher default risk premium than larger ones. This empirical evidence is also in concordance with the fact that the three

\footnotetext{
21 These results seem consistent; they point out that, since EMU, market assessment of both liquidity and default risk (whose measurement, see p.12 in section 4 , is difficult because the two variables interact with each other) is closely related within countries as it depends on the size of their debt market.
} 
countries that account for around 59\% of the euro-area government securities markets (Italy, France and Spain) are precisely the ones with lowest adjusted spread rise since Monetary Integration (see tables 1a and 1b).

As mentioned, international risk factors appear less significant than local ones in explaining adjusted spread changes. In addition, default risk only seems to be relevant when it is accompanied by a small market size. These results then show that the theory "too big to fail" holds: it is expected that large countries will receive financial support in case of fiscal distress (bail-out). This explains why the default risk premium has decreased for some big countries since EMU. In small countries, on the other hand, markets expect that the "no-bail-out" clause will hold, and membership of the monetary union has increased the default risk since these countries have lost monetary authority. In Italy, for instance, in spite of its very high debt-to-GDP ratio, the associated default risk might be compensated by both the increased liquidity characteristic of a big market and the lack of credibility of the no-bail-out clause.

Finally, these results reinforce the self-fulfilling nature of market liquidity. Both in the case of the smallest or the largest debt markets, illiquidity or liquidity presents a non-linear behaviour that supports the idea that traders' transactions flee from illiquid to liquid debt markets. So, the more liquid (illiquid) a market is, the more traders want (do not want) to participate in it, resulting in an increase (decrease) in the liquidity of the market. In particular, as the German sovereign debt market is the second-biggest in the euro-area (only surpassed by the Italian), both a concentration of trading activity and a drop in the credibility of the "no-bail-out" rule might have occurred in the German market. Consequently, wider liquidity and perceived default risk differences vis-à-vis German bonds might have been transformed into higher adjusted spreads.

To conclude, with the introduction of a common currency and in the current context of higher competition between euro-area government securities markets, the success of euro-area sovereign securities debt markets may be highly dependent on their market size.

\section{Acknowledgments}

The backbone of this paper was written while I was a Visiting Scholar at the Economics Department of the Massachusetts Institute of Technology (September 2000-August 2002). I would like to thank MIT Economics Department for their hospitality, the Spanish Ministry of Education for their financial support, and both Campe Goodman and Analistas Financieros Internacionales S.A. who kindly provided part of the data used in the empirical analysis. I am grateful to Rudi Dornbusch, Roberto Rigobon and all the participants at the International Breakfast Workshop at MIT for their useful comments on a very preliminary draft . Special thanks to Lorenzo Codogno, Jordi Galí, Alessandro Missale, Juergen von Hagen, Jaume Ventura, and the participants at various conferences where it has been presented, for their insightful comments on previous versions of the paper. Finally, I would like to give special thanks to an anonymous referee for his/her wise comments. I alone am responsible for any errors remaining in the final version. 


\section{References}

Adjaouté, K, L.Bottazi, J.P.Danthine, A.Fischer, R.Hamaui, R.Portes and M.Wickens, 2000. EMU and Portfolio Adjustment. CEPR Policy Paper N5.

Alesina, A., M. De Broeck, A. Prati and G.Tabellini, 1992. Default risk on government debt in OECD countries. Economic Policy, October, pp. 428-463.

Arnold, I. and J. Lemmen, 2001. The Vulnerability of Banks to Government Default Risk in the EMU. International Finance n.4, vol.1, pp. 101-125.

Bickser, J. and A. Chen, 1986. An Economic Analysis of Interest Rate Swaps. The Journal of Finance vol. XLI, n.3. July, pp.645-655.

Bank for International Settlements, 1999. Market Liquidity: Research Findings and Selected Policy Implications. Committee on the Global Financial System Publications n.11.

Bank for International Settlements Study group on fixed income markets, 2001. The changing shape of fixed income markets. BIS Working Papers 104, September.

Bank for International Settlements, 2002. Quaterly Review, December.

Bernoth, K, J.Von Hagen and L. Schuknecht, 2004. Sovereign risk premia in the European Government Bond Market. European Central Bank working paper n. 369, June.

Blanco, R., 2001. The euro-area Government Securities Market: Recent Developments and Implications for Market Functioning. Documento de trabajo del Banco de España n. 0120.

Bayoumi, T. M.Goldstein and G.Woglom, 1995. Do Credit Markets Discipline Sovereign Borrowers? Evidence from the US States. Journal of Money Credit and Banking 27 (4) pp.1046-1059.

Codogno, L., C.Favero and A. Missale, 2003. EMU and Government Bond Spreads. Economic Policy n.18, pp.503-532.

Danthine, J.P., F.Giavazzi and E.L von Thadden, 2001. European Financial Markets after EMU: A First Assessment. In: Wyplosz, C. (Ed), The Impact of EMU on Europe and the Developing countries. University Press, Oxford.

Duffie, D. and K. Singleton, 1997. An Econometric Model of the Term Structure of Interest Swap Spreads. The Journal of Finance vol. 52, pp.1287-1321. 
Economides, N. and A.Siow, 1988. The Division of Markets is Limited by the Extent of Liquidity (Spatial Competition with Externalities). American Economic Review, Vol.78, n¹ pp 1719-1734.

Favero, C., F. Giavazzi and L. Spaventa, 1997. High Yields: The Spread on German Interest Rate. The Economic Journal, Vol.107, Issue 443.

Favero, Missale, and Piga, 1999. EMU and Public Debt Management: One Money, One Debt? .CEPR Policy Paper n.3, December.

Fleming, M.J., 2003. Measuring Treasury Market Liquidity. Federal Reserve Bank of New Economic Policy Review 9, pp.83-108.

Goodhart, C.A.E. and H. Huang, 2005. The lender of last resort. Journal of Banking \& Finance n.29, pp.1059-1082.

Gómez-Puig, M., 2005. Size Matters for Liquidity: Evidence from EMU sovereign yield spreads. Forthcoming in Economics Letters.

Giovannini, A. and G.Piga, 1994. Understanding the High Interest Rates on Italian Government Securities; Bond Markets, Treasury and Debt Management: The Italian case, pp.13-29. London, New York and Melbourne Chapman and Hall in collaboration with the European Economics and Financial Centre.

He. H., 2000. Modeling Term Structures of Swap Spreads. Working Paper, Yale University.

Helpman, E., and Krugman, P., 1985 Market Structure and Foreign Trade. MIT Press, Cambridge, MA.

Kaufman, G.G. 2002. Too big to fail in banking: What remains?. The Quarterly Journal of Finance n. 42, pp.423-436.

Liu, J. F.A. Longstaff, R.E. Mandell, 2002. The Market Price of Credit Risk: An Empirical Analysis of Interest Rate Swap Spreads. National Bureau of Economic Research Working Paper n. 8990, June.

Martin, P and H.Rey, 2004. Financial super-markets: size matters for asset trade. Journal of International Economics 64, pp. 335-361.

McCauley R. and E.Remolona, 2000. Size and Liquidity of Government Bond Markets. BIS Quarterly Review, November.

Plantin, G., 2003. Self-Fulfilling Liquidity and the Coordination Premium. Financial Markets Group Discussion Paper n. 450, April. 
Tesar, L. and I. Werner, 1995. Home bias and high turnover. Journal of International Money and Finance, Vol.14, N4, pp.467-492.

Vayanos, L., 2004. Flight to quality, flight to liquidity and the pricing of risk. NBER working paper n.10327, February. 
FIGURE 1

10 YEAR YIELD DIFFERENTIALS OVER GERMANY

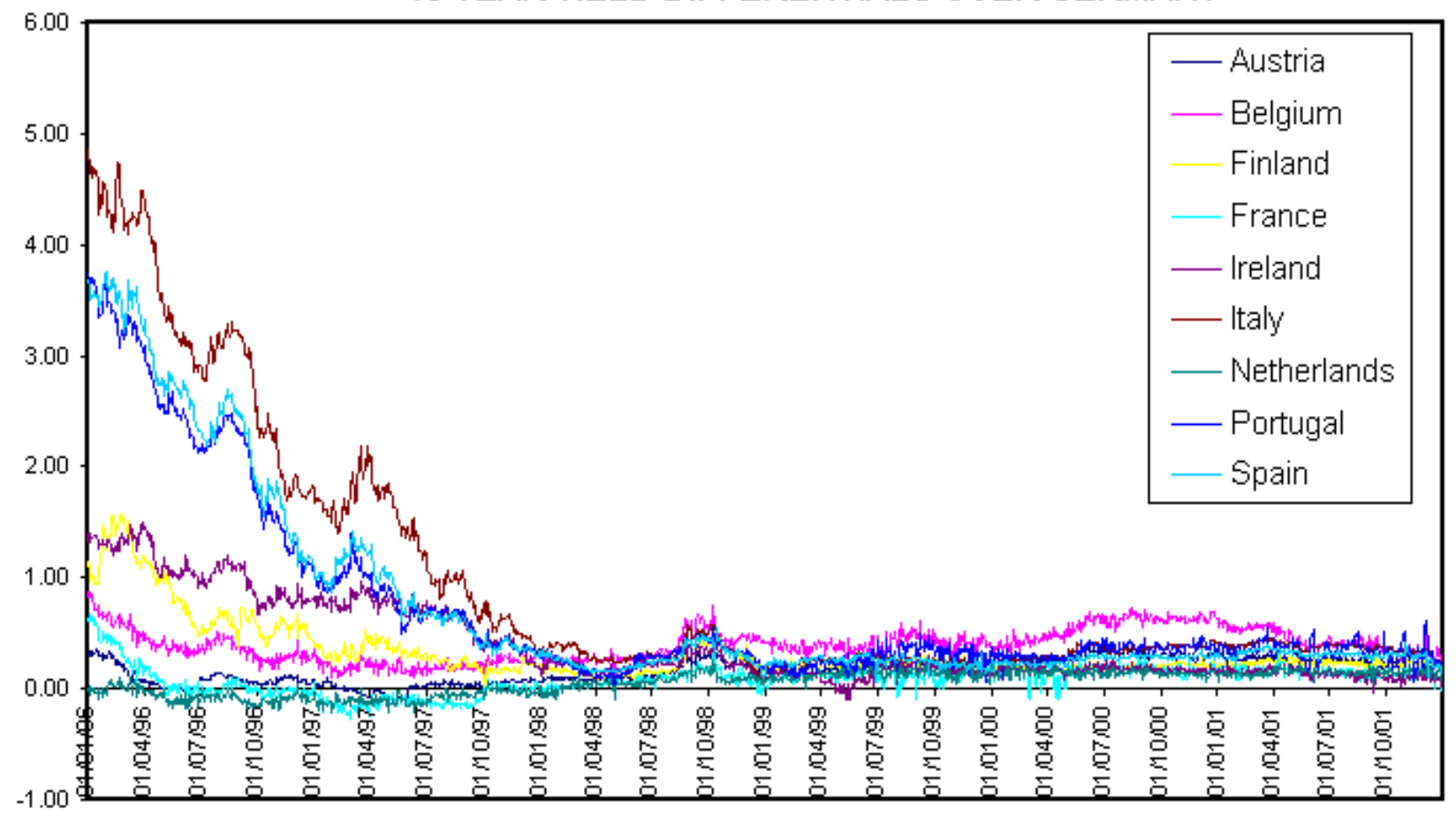

NOTE: Yield differential $=\left(\mathrm{I}_{\mathrm{i}}-\mathrm{I}_{\mathrm{DM}}\right)$, where $\mathrm{I}_{\mathrm{i}}$ is the 10 -year yield on country $\mathrm{i}$ government bonds and $\mathrm{I}_{\mathrm{DM}}$ is the 10 year yield on Germany government bonds.

Source : Datastream 
FIGURE 2

10 YEARS SWAP RATE DIFFERENTIALS OVER GERMANY

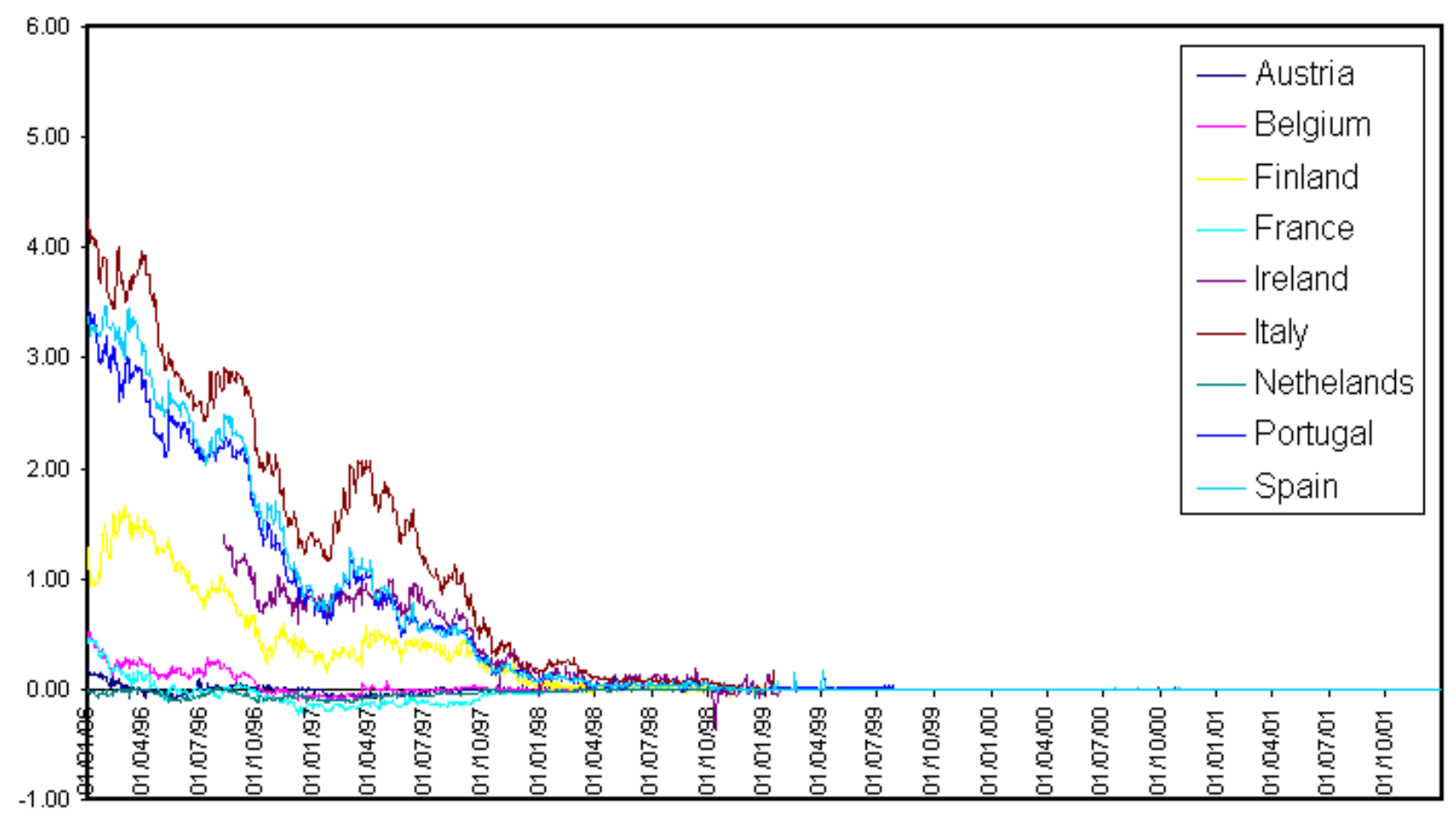

NOTE: Swap differential $=\left(\right.$ IRS $\left._{\mathrm{i}}-\mathrm{IRS}_{\mathrm{DM}}\right)$, where $\mathrm{IRS}_{\mathrm{i}}$ is the 10 -year interest rate swap of currency $i$ and IRS $_{\mathrm{DM}}$ is the 10-year interest rate swap of the D-mark.

Source :Datastream 
FIGURE 3

10 YEARS ADJUSTED YIELD SPREADS OVER GERMANY

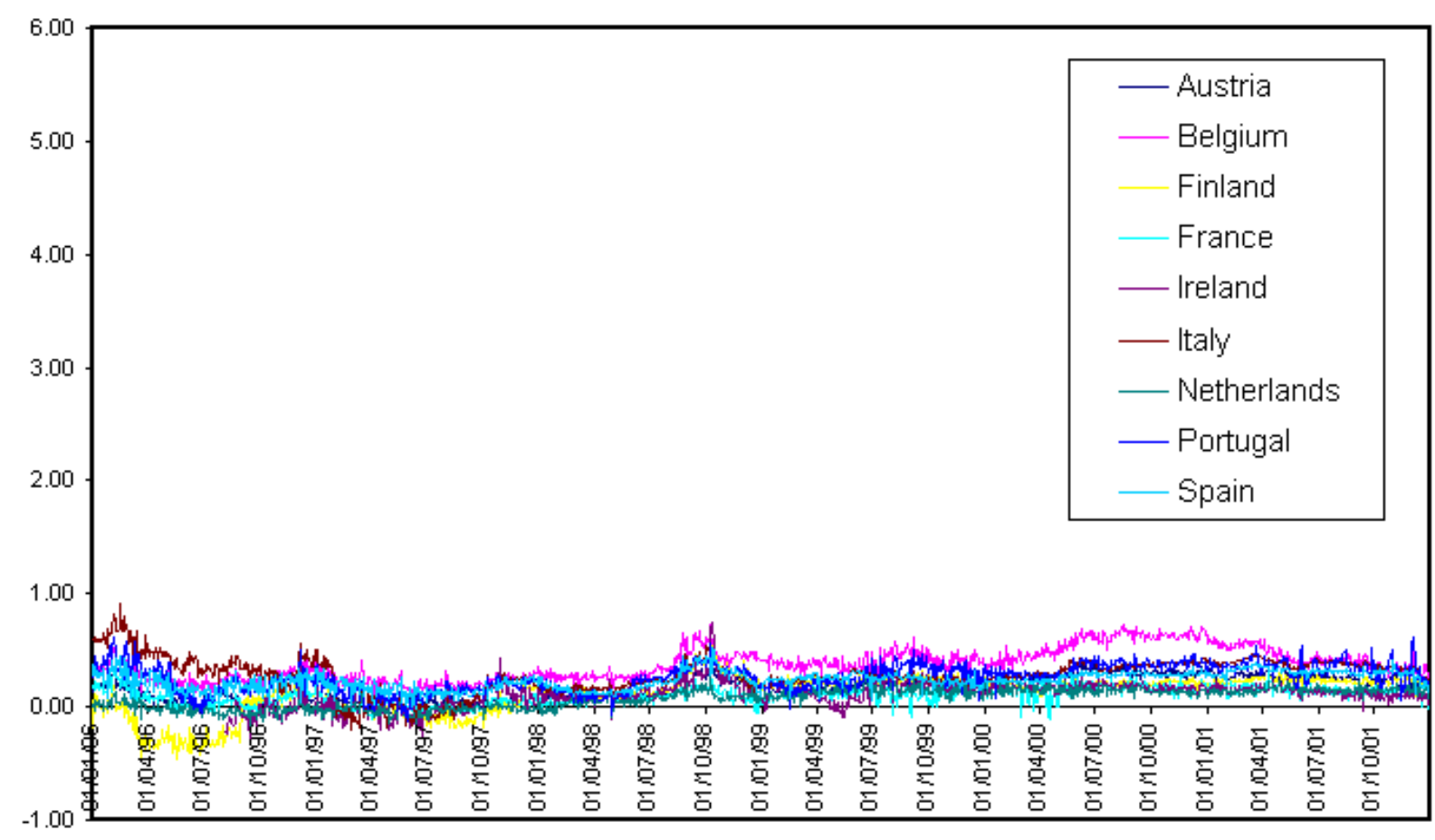

NOTE: Adjusted yield spread $=$ Yield differential - Swap differential $=\left(\mathrm{I}_{\mathrm{i}}-\mathrm{I}_{\mathrm{DM}}\right)-\left(\mathrm{IRS}_{\mathrm{i}}-\mathrm{IRS}_{\mathrm{DM}}\right)$. Source: Datastream. 
TABLE 1a

\begin{tabular}{|c|c|c|c|c|c|c|}
\hline & \multicolumn{3}{|c|}{ PRE-EMU (1996-1998) } & \multicolumn{3}{|c|}{ EMU (1999-2001) } \\
\hline & $\left(\mathbf{l}_{\mathbf{i}}-\mathbf{D}_{\mathrm{DM}}\right)$ & $\left(\mathbf{I R S}_{\mathrm{i}}-\mathbf{I R S}_{\mathrm{DM}}\right)$ & ASPREAD $_{\mathrm{i}}$ & $\left(I_{i}-I_{D M}\right)$ & $\left(\mathrm{IRS}_{\mathrm{i}}-\mathrm{IRS}_{\mathrm{DM}}\right)$ & ASPREAD \\
\hline & (1) & (2) & $(3)=(1)-(2)$ & (4) & (5) & $(6)=(4)-(5)$ \\
\hline AT & 9.07 & -0.33 & 9.40 & 24.42 & -0.01 & 24.43 \\
\hline BE & 33.06 & 4.29 & 28.77 & 46.30 & -0.01 & 46.31 \\
\hline FI & 43.56 & 41.31 & 2.25 & 21.95 & -0.01 & 21.96 \\
\hline FR & 2.97 & -3.10 & 6.07 & 14.05 & 0.00 & 14.05 \\
\hline IE & 50.52 & 43.84 & 6.68 & 14.78 & 0.00 & 14.78 \\
\hline IT & 157.73 & 133.04 & 24.69 & 32.32 & 0.05 & 32.27 \\
\hline NL & -2.70 & -3.52 & 0.83 & 14.22 & -0.01 & 14.23 \\
\hline PT & 111.73 & 91.42 & 20.31 & 31.85 & 0.22 & 31.63 \\
\hline SP & 118.06 & 97.99 & 20.07 & 27.24 & 0.04 & 27.20 \\
\hline Average & 58.22 & 44.99 & 13.23 & 25.24 & 0.03 & 25.21 \\
\hline St.dev. & 57.48 & 51.37 & 10.33 & 10.66 & 0.08 & 10.64 \\
\hline
\end{tabular}

NOTE: AT: Austria, BE: Belgium, FI: Finland, FR: France, IE: Ireland, IT: Italy, NL: The Netherlands, PT: Portugal, SP: Spain. Source: Datastream.

$\left(\mathrm{I}_{\mathrm{i}}-\mathrm{I}_{\mathrm{DM}}\right)=10$-year yield difference over Germany

$\left(\mathrm{IRS}_{\mathrm{i}}-\mathrm{IRS}_{\mathrm{DM}}\right)=10$-year interest rate swap difference over Germany

ASPREAD $_{\mathrm{i}}=\left(\mathrm{I}_{\mathrm{i}}-\mathrm{I}_{\mathrm{DM}}\right)-\left(\mathrm{IRS}_{\mathrm{i}}-\mathrm{IRS}_{\mathrm{DM}}\right)$ 


\section{TABLE 1b}

\begin{tabular}{|l|cc|}
\hline \multicolumn{3}{|c|}{ Differences between EMU and pre-EMU } \\
\hline & $\left(\mathbf{i}_{i}-\mathbf{i}_{\text {DM }}\right)$ & ASPREAD $_{\mathrm{i}}$ \\
\cline { 2 - 3 } & $(\mathbf{4})-(\mathbf{1})$ & $(6)-(3)$ \\
\hline AT & 15.34 & 15.03 \\
BE & 13.24 & 17.53 \\
FI & -21.61 & 19.71 \\
FR & 11.08 & 7.98 \\
IE & -35.74 & 8.10 \\
IT & -125.40 & 7.58 \\
NL & 16.92 & 13.40 \\
PT & -79.88 & 11.31 \\
SP & -90.82 & 7.13 \\
& & \\
\hline Average & $\mathbf{- 3 2 . 9 9}$ & $\mathbf{1 1 . 9 8}$ \\
St.dev. & 53.77 & 4.69 \\
\hline
\end{tabular}

NOTE: AT: Austria, BE: Belgium, FI: Finland, FR: France, IE: Ireland, IT: Italy, NL: The Netherlands, PT: Portugal, SP: Spain. Source: Datastream.

$\left(\mathrm{I}_{\mathrm{i}}-\mathrm{I}_{\mathrm{DM}}\right)=10$-year yield difference over Germany

$\left(\mathrm{IRS}_{\mathrm{i}}-\mathrm{IRS}_{\mathrm{DM}}\right)=10$-year interest rate swap difference over Germany

ASPREAD $_{\mathrm{i}}=\left(\mathrm{I}_{\mathrm{i}}-\mathrm{I}_{\mathrm{DM}}\right)-\left(\mathrm{IRS}_{\mathrm{i}}-\mathrm{IRS}_{\mathrm{DM}}\right)$ 
TABLE 2

\begin{tabular}{|c|c|c|c|c|c|c|c|c|c|}
\hline \multicolumn{10}{|c|}{$\begin{array}{c}\text { DOMESTIC DEBT SECURITIES } \\
\text { PUBLIC SECTOR AMOUNTS OUTSTANDING } \\
\text { (Billions of euros) }\end{array}$} \\
\hline & 1995-12 & 1996-12 & 1997-12 & 1998-12 & 1999-12 & $2000-12$ & 2001-12 & average & $\%$ over EMU \\
\hline Ireland & 19.93 & 23.20 & 23.12 & 21.93 & 24.73 & 24.07 & 19.95 & 23.15 & 0.69 \\
\hline Portugal & 35.19 & 36.47 & 32.84 & 34.04 & 37.49 & 42.35 & 45.61 & 37.67 & 1.13 \\
\hline Finland & 33.20 & 38.15 & 41.56 & 44.28 & 45.60 & 47.70 & 46.28 & 43.39 & 1.30 \\
\hline Austria & 57.04 & 58.95 & 63.87 & 69.28 & 86.05 & 99.74 & 100.52 & 76.80 & 2.30 \\
\hline Greece & 64.10 & 79.58 & 84.47 & 84.80 & 88.43 & 96.73 & 102.20 & 87.23 & 2.62 \\
\hline Netherlands & 155.64 & 159.89 & 159.68 & 170.12 & 178.14 & 180.98 & 177.50 & 171.44 & 5.14 \\
\hline Belgium & 228.86 & 230.59 & 228.41 & 229.67 & 231.85 & 246.18 & 248.66 & 236.75 & 7.10 \\
\hline Spain & 211.07 & 241.63 & 259.63 & 272.41 & 287.34 & 311.04 & 299.43 & 269.56 & 8.09 \\
\hline France & 497.35 & 536.05 & 565.50 & 623.91 & 639.85 & 708.45 & 709.23 & 614.79 & 18.45 \\
\hline Germany & 676.53 & 682.74 & 699.45 & 738.75 & 767.35 & 816.77 & 790.81 & 734.97 & 22.05 \\
\hline Italy & 896.49 & 1022.19 & 1011.08 & 1037.09 & 1042.62 & 1088.36 & 1056.96 & 1036.69 & 31.11 \\
\hline EMU & 2875.40 & 3109.45 & 3169.63 & 3326.27 & 3429.43 & 3662.37 & 3597.15 & 3332.43 & 100.00 \\
\hline
\end{tabular}

Source: Bank for International Settlements. 
TABLE 3

\begin{tabular}{|c|c|c|c|c|}
\hline & Starting date as a benchmark & Name & Coupon & Maturity date \\
\hline \multicolumn{5}{|l|}{ AUSTRIA } \\
\hline & $\begin{array}{l}\text { Dec-95 } \\
\text { Mar-96 } \\
\text { Jul-96 } \\
\text { Nov-96 } \\
\text { Feb-97 } \\
\text { Jun-97 } \\
\text { Sep-97 } \\
\text { Feb-98 } \\
\text { Apr-99 } \\
\text { Dec-99 } \\
\text { May-01 }\end{array}$ & $\begin{array}{l}\text { OESTERREICH } \\
\text { OESTERREICH } \\
\text { OESTERREICH } \\
\text { OESTERREICH } \\
\text { OESTERREICH } \\
\text { OESTERREICH } \\
\text { OESTERREICH } \\
\text { OESTERREICH } \\
\text { OESTERREICH } \\
\text { OESTERREICH } \\
\text { OESTERREICH }\end{array}$ & \begin{tabular}{|l|}
$19956.5 \%$ \\
$19966.125 \%$ \\
$19966.25 \%$ \\
$19965.875 \%$ \\
$19975.625 \%$ \\
$199753 / 4 \%$ \\
$199755 / 8 \%$ \\
$19985 \%$ \\
$19994 \%$ \\
$199951 / 2 \%$ \\
$200151 / 4 \%$ \\
\end{tabular} & $\begin{array}{l}17 / 11 / 05 \\
09 / 02 / 06 \\
31 / 05 / 06 \\
15 / 07 / 06 \\
17 / 01 / 07 \\
11 / 04 / 07 \\
15 / 07 / 07 \\
15 / 01 / 08 \\
15 / 07 / 09 \\
15 / 01 / 10 \\
04 / 01 / 11\end{array}$ \\
\hline \multicolumn{5}{|l|}{ BELGIUM } \\
\hline & $\begin{array}{l}\text { Feb-95 } \\
\text { Mar-96 } \\
\text { Jan-97 } \\
\text { Dec-97 } \\
\text { Feb-99 } \\
\text { Feb-00 } \\
\text { May-01 }\end{array}$ & $\begin{array}{l}\text { BELGIUM OLO } \\
\text { BELGIUM OLO } \\
\text { BELGIUM OLO } \\
\text { BELGIUM OLO } \\
\text { BELGIUM OLO } \\
\text { BELGIUM OLO } \\
\text { BELGIUM OLO }\end{array}$ & $\begin{array}{l}19946.5 \% \\
19957 \% \\
199661 / 4 \% \\
199753 / 4 \% \\
199933 / 4 \% \\
200053 / 4 \% \\
20015 \%\end{array}$ & $\begin{array}{l}31 / 03 / 05 \\
15 / 05 / 06 \\
28 / 03 / 07 \\
28 / 03 / 08 \\
28 / 03 / 09 \\
28 / 09 / 10 \\
28 / 09 / 11\end{array}$ \\
\hline \multicolumn{5}{|l|}{ FINLAND } \\
\hline & $\begin{array}{l}\text { Jul-93 } \\
\text { Sep-96 } \\
\text { Dec-97 } \\
\text { Dec-98 } \\
\text { Feb-00 }\end{array}$ & $\begin{array}{l}\text { FINLAND } \\
\text { FINLAND } \\
\text { FINLAND } \\
\text { FINLAND } \\
\text { FINLAND }\end{array}$ & \begin{tabular}{|l|}
19939 1/2\% \\
$199671 / 4 \%$ \\
$19976 \%$ \\
$19985 \%$ \\
$200053 / 4 \%$ \\
\end{tabular} & $\begin{array}{l}15 / 03 / 04 \\
18 / 04 / 06 \\
25 / 04 / 08 \\
25 / 04 / 09 \\
23 / 02 / 11\end{array}$ \\
\hline \multicolumn{5}{|l|}{ FRANCE } \\
\hline & $\begin{array}{l}\text { Aug-95 } \\
\text { Feb-96 } \\
\text { Oct-96 } \\
\text { Apr-97 } \\
\text { Oct-97 } \\
\text { Mar-98 } \\
\text { Nov-98 } \\
\text { Jan-99 } \\
\text { Jul-99 } \\
\text { Mar-00 } \\
\text { Sep-00 } \\
\text { Jun-01 }\end{array}$ & $\begin{array}{l}\text { OAT FRANCE } \\
\text { OAT FRANCE } \\
\text { OAT FRANCE } \\
\text { OAT FRANCE } \\
\text { OAT FRANCE } \\
\text { OAT FRANCE } \\
\text { OAT FRANCE } \\
\text { OAT FRANCE } \\
\text { OAT FRANCE } \\
\text { OAT FRANCE } \\
\text { OAT FRANCE } \\
\text { OAT FRANCE }\end{array}$ & $\begin{array}{l}199573 / 4 \% \\
19957.25 \% \\
19956.50 \% \\
19965.5 \% \\
19975.5 \% \\
19985.25 \% \\
1998 \text { 8.5\% } \\
1998 \text { 4\% } \\
19994 \% \\
20005.5 \% \\
20005.5 \% \\
20016.5 \% \\
\end{array}$ & $\begin{array}{l}25 / 10 / 05 \\
25 / 04 / 06 \\
25 / 10 / 06 \\
25 / 04 / 07 \\
25 / 10 / 07 \\
25 / 04 / 08 \\
25 / 10 / 08 \\
25 / 04 / 09 \\
25 / 10 / 09 \\
25 / 04 / 10 \\
25 / 10 / 10 \\
25 / 04 / 01\end{array}$ \\
\hline \multicolumn{5}{|l|}{ GERMANY } \\
\hline & $\begin{array}{l}\text { Nov-95 } \\
\text { Feb-96 } \\
\text { Mar-96 } \\
\text { Jun-96 } \\
\text { Feb-97 } \\
\text { May-97 } \\
\text { Feb-98 } \\
\text { Aug-98 } \\
\text { Feb-99 } \\
\text { Apr-99 } \\
\text { Aug-99 } \\
\text { Nov-99 } \\
\text { Jun-00 } \\
\text { Dec-00 } \\
\text { Jun-01 }\end{array}$ & $\begin{array}{l}\text { BUNDESREPUB.DTL } \\
\text { BUNDESREPUB.DTL } \\
\text { BUNDESREPUB.DTL } \\
\text { BUNDESREPUB.DTL } \\
\text { BUNDESREPUB.DTL } \\
\text { BUNDESREPUB.DTL } \\
\text { BUNDESREPUB.DTL } \\
\text { BUNDESREPUB.DTL } \\
\text { BUNDESREPUB.DTL } \\
\text { BUNDESREPUB.DTL } \\
\text { BUNDESREPUB.DTL } \\
\text { BUNDESREPUB.DTL } \\
\text { BUNDESREPUB.DTL } \\
\text { BUNDESREPUB.DTL } \\
\text { BUNDESREPUB.DTL }\end{array}$ & $\begin{array}{l}199561 / 2 \% \\
19966 \% \\
19966 \% \\
199661 / 4 \% \\
19976 \% \\
19976 \% \\
199851 / 4 \% \\
199843 / 4 \% \\
199933 / 4 \% \\
19994 \% \\
199941 / 2 \% \\
199953 / 8 \% \\
200051 / 4 \% \\
200051 / 4 \% \\
20015 \%\end{array}$ & $\begin{array}{l}14 / 10 / 05 \\
05 / 01 / 06 \\
16 / 02 / 06 \\
26 / 04 / 06 \\
04 / 01 / 07 \\
04 / 07 / 07 \\
04 / 01 / 08 \\
04 / 07 / 08 \\
04 / 01 / 09 \\
04 / 07 / 09 \\
04 / 07 / 09 \\
04 / 01 / 10 \\
04 / 07 / 10 \\
04 / 01 / 11 \\
04 / 07 / 11\end{array}$ \\
\hline
\end{tabular}


TABLE 3 (Continuation)

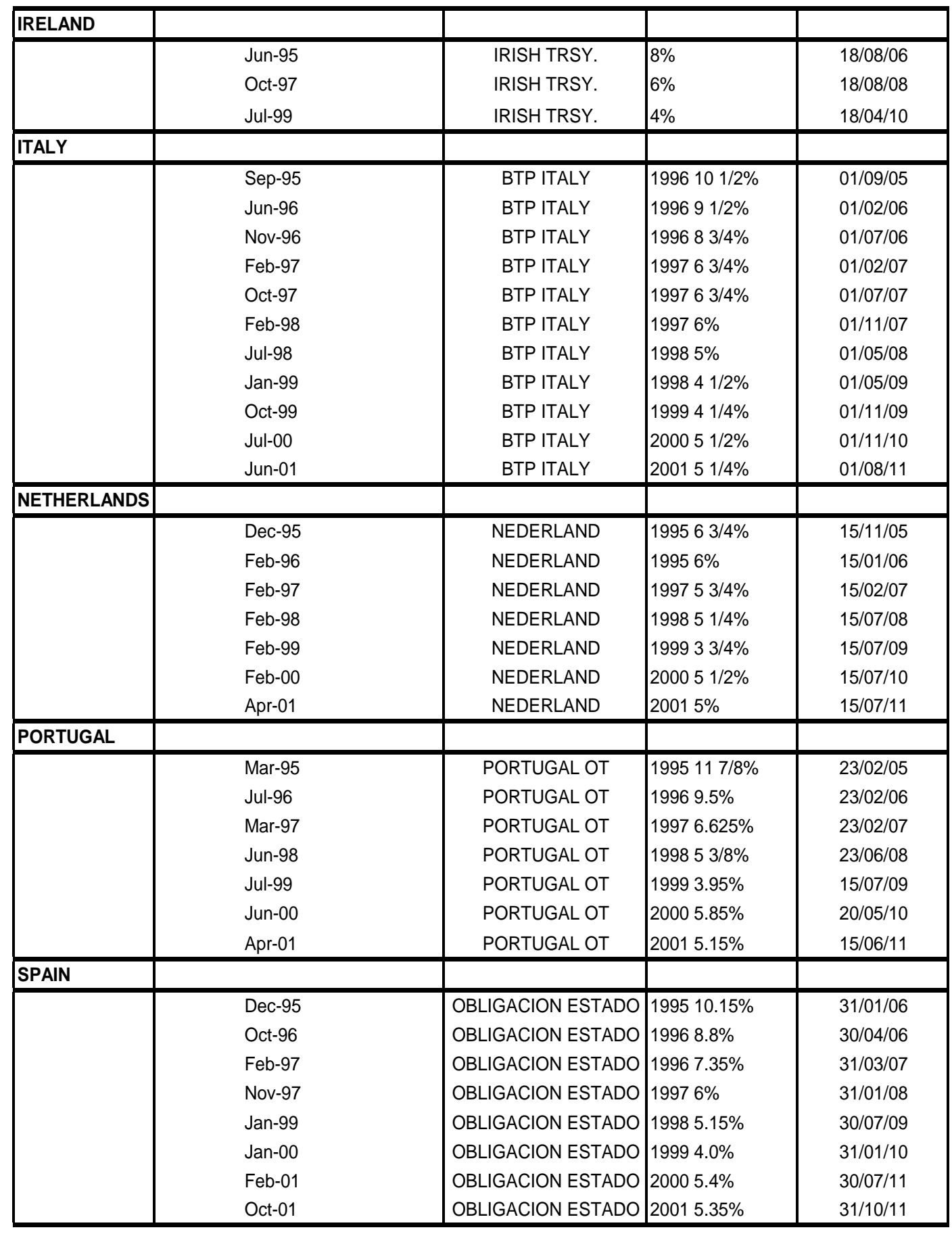

Source: Datastream 
TABLES 4 and 5

\begin{tabular}{|c|c|c|c|c|}
\hline \multicolumn{5}{|c|}{$\begin{array}{l}\text { Cross-Sectional Time-Serie FGLS Regression. } \\
\text { Sample: Pre-EMU: 1996:01-1998:12 } \\
\text { EMU: 1999:01-2001:12 } \\
\text { dependent variable: } \boldsymbol{A S P R E A D}\end{array}$} \\
\hline \multirow[b]{3}{*}{$\boldsymbol{X}_{i t}$} & \multicolumn{2}{|c|}{ TABLE 4} & \multicolumn{2}{|c|}{ TABLE 5} \\
\hline & \multicolumn{2}{|c|}{ SPECIFICATION I (STATIC MODEL) } & \multicolumn{2}{|c|}{ SPECIFICATION II (DYNAMIC MODEL) } \\
\hline & $\overline{\beta_{1}\left(X_{i t}\right)}$ & $\beta_{2}\left(D P R E_{i t} * X_{i t}\right)$ & $\beta_{1}\left(X_{i t}\right)$ & $\beta_{2}\left(D P R E_{i t} * X_{i t}\right)$ \\
\hline ASPREAD $_{\text {it-1 }}$ & & & $\begin{array}{l}0.640^{\star \star} \\
(0.010) \\
\end{array}$ & $\begin{array}{l}0.114^{\star *} \\
(0.011)\end{array}$ \\
\hline$L_{N D E B T G D P_{i t}}$ & $\begin{array}{l}0.181^{\star *} \\
(0.008)\end{array}$ & $\begin{array}{c}-0.017^{\star \star} \\
(0.002)\end{array}$ & $\begin{array}{l}0.064^{* *} \\
(0.006)\end{array}$ & $\begin{array}{l}-0.014^{\star \star} \\
(0.001)\end{array}$ \\
\hline ONOFFDIF $_{i t}$ & $\begin{array}{l}1.782^{\star \star} \\
(0.104)\end{array}$ & $\begin{array}{c}-1.082^{\star \star} \\
(0.118) \\
\end{array}$ & $\begin{array}{l}0.565^{\star \star} \\
(0.072)\end{array}$ & $\begin{array}{l}-0.301^{* *} \\
(0.079)\end{array}$ \\
\hline ONOFFDIF2 ${ }_{\text {it }}$ & $\begin{array}{c}-10.686^{\star \star *} \\
(0.608)\end{array}$ & $\begin{array}{l}5.133^{\star \star} \\
(0.616) \\
\end{array}$ & $\begin{array}{l}-3.374^{\star \star} \\
(0.423)\end{array}$ & $\begin{array}{c}1.656 \\
(0.423) \\
\end{array}$ \\
\hline BIDASKDIF $_{i t}$ & $\begin{array}{l}0.557^{\star \star} \\
(0.050) \\
\end{array}$ & $\begin{array}{l}-0.386^{\star \star} \\
(0.075) \\
\end{array}$ & $\begin{array}{l}0.244^{\star *} \\
(0.035) \\
\end{array}$ & $\begin{array}{l}-0.224^{\star *} \\
(0.053) \\
\end{array}$ \\
\hline BIDASKDIF2 $_{\text {it }}$ & - & $\begin{array}{l}-2.670^{* *} \\
(0.742)\end{array}$ & - & - \\
\hline USSPREAD $_{i t}$ & $\begin{array}{l}0.034^{* *} \\
(0.007) \\
\end{array}$ & $\begin{array}{l}-0.018^{* *} \\
(0.009) \\
\end{array}$ & $\begin{array}{l}0.008^{*} \\
(0.005) \\
\end{array}$ & - \\
\hline LNDEBTGDP*USSPREAD $_{i t}$ & $\begin{array}{l}0.050^{\star *} \\
(0.003) \\
\end{array}$ & $\begin{array}{c}-0.082^{* *} \\
(0.003)\end{array}$ & $\begin{array}{l}0.014^{\star *} \\
(0.002) \\
\end{array}$ & $\begin{array}{l}-0.024^{* \star} \\
(0.002)\end{array}$ \\
\hline ONOFFDIF*USSPREAD $_{\text {it }}$ & $\begin{array}{c}-1.860^{* \star} \\
(0.106) \\
\end{array}$ & $\begin{array}{l}0.899^{\star *} \\
(0.145) \\
\end{array}$ & $\begin{array}{l}-0.590^{\star \star} \\
(0.076)\end{array}$ & $\begin{array}{l}0.222^{* *} \\
(0.098) \\
\end{array}$ \\
\hline ONOFFDIF2*USSPREAD ${ }_{i t}$ & $\begin{array}{c}15.425^{\star \star} \\
(0.720) \\
\end{array}$ & $\begin{array}{l}-6.340^{\star *} \\
(0.726) \\
\end{array}$ & $\begin{array}{l}4.877^{\star \star} \\
(0.499) \\
\end{array}$ & $\begin{array}{l}-2.067^{\star \star} \\
(0.490)\end{array}$ \\
\hline BIDASKDIF*USSPREAD $_{i t}$ & $\begin{array}{l}-0.401^{\star \star} \\
(0.059)\end{array}$ & - & $\begin{array}{l}-0.217^{\star \star} \\
(0.039)\end{array}$ & $\begin{array}{c}0.150 \\
(0.076) \\
\end{array}$ \\
\hline BIDASKDIF2*USSPREAD $_{i t}$ & - & $\begin{array}{l}4.301^{\star *} \\
(0.731)\end{array}$ & $\begin{array}{l}0.651^{*} \\
(0.403)\end{array}$ & - \\
\hline & $\lambda_{i}$ & & $\lambda_{i}$ & \\
\hline DBELGIUM & $\begin{array}{l}-0.121^{\star *} \\
(0.008) \\
\end{array}$ & & $\begin{array}{c}-0.041^{\star \star} \\
(0.005) \\
\end{array}$ & \\
\hline DIRELAND & - & & - & \\
\hline DITALY & $\begin{array}{l}-0.032^{\star \star} \\
(0.007) \\
\end{array}$ & & $\begin{array}{l}-0.015^{\star \star} \\
(0.005)\end{array}$ & \\
\hline DFINLAND & $\begin{array}{l}-0.009^{* *} \\
(0.003)\end{array}$ & & - & \\
\hline DFRANCE & $\begin{array}{l}-0.097^{\star \star} \\
(0.002)\end{array}$ & & $\begin{array}{l}-0.033^{\star \star} \\
(0.002)\end{array}$ & \\
\hline DNETHERLANDS & $\begin{array}{l}0.131^{\star \star} \\
(0.010)\end{array}$ & & $\begin{array}{l}0.045^{\star \star} \\
(0.007)\end{array}$ & \\
\hline DPORTUGAL & $\begin{array}{l}0.150^{\star *} \\
(0.007)\end{array}$ & & $\begin{array}{l}0.047^{\star *} \\
(0.005)\end{array}$ & \\
\hline DSPAIN & $\begin{array}{l}0.027^{\star \star} \\
(0.002)\end{array}$ & & $\begin{array}{l}0.006^{\star *} \\
(0.002)\end{array}$ & \\
\hline & $\gamma$ & & $\gamma$ & \\
\hline$D P R E_{i t}$ & $\begin{array}{l}0.038^{\star \star} \\
(0.009)\end{array}$ & & $\begin{array}{l}-0.017^{\star \star} \\
(0.007)\end{array}$ & \\
\hline & $\alpha$ & & $\alpha$ & \\
\hline CONSTANT & $\begin{array}{l}0.160^{\star *} \\
(0.005)\end{array}$ & & $\begin{array}{l}0.062^{* *} \\
(0.004)\end{array}$ & \\
\hline $\begin{array}{l}\text { Number of observations = } \\
\text { Number of groups = } \\
\text { Avg obs per group = } \\
\text { Log likelihood = } \\
\text { Wald chi2 = } \\
\text { Prob }>\text { chi2 = }\end{array}$ & $\begin{array}{c}12139 \\
9 \\
1406 \\
23893.12 \\
53337.41 \\
0.00\end{array}$ & & $\begin{array}{c}12132 \\
9 \\
1406 \\
28095.75 \\
130752.29 \\
0.00\end{array}$ & \\
\hline
\end{tabular}

**Significant at 5 percent confidence level.

* Significant at 10 percent confidence level.

Standard Errors within parentheses 
TABLE 6

SPECIFICATION III (STATIC MODEL)

Regression with Newey-West Standard Errors

Sample: Pre-EMU: 1996:01-1998:12

EMU: 1999:01-2001:12
dependent variabe: $A S P E A D$

\begin{tabular}{|c|c|c|c|c|c|c|c|c|c|c|c|c|c|c|c|c|c|c|}
\hline \multirow[b]{2}{*}{$X_{t}$} & \multicolumn{2}{|c|}{ AUSTRIA } & \multicolumn{2}{|c|}{ BELGIUM } & \multicolumn{2}{|c|}{ FINLAND } & \multicolumn{2}{|r|}{ FRANCE } & \multicolumn{2}{|c|}{ IRELAND } & \multicolumn{2}{|c|}{ ITALY } & \multicolumn{2}{|c|}{$\begin{array}{l}\text { THE NETHERLANDS } \\
\end{array}$} & \multicolumn{2}{|c|}{ PORTUGAL } & \multicolumn{2}{|c|}{ SPAIN } \\
\hline & $B_{1}\left(X_{t}\right)$ & $\beta_{2}\left(D P R E^{*} X_{t}\right)$ & $\beta_{1}\left(X_{t}\right)$ & $B_{2}\left(\right.$ DPRE $\left.^{*} X_{t}\right)$ & $B_{1}\left(X_{t}\right)$ & $\beta_{2}\left(\right.$ DPRE $\left.^{*} X_{t}\right)$ & $B_{1}\left(X_{t}\right)$ & $\beta_{2}\left(D P R E^{*} X_{t}\right)$ & $\beta_{1}\left(X_{t}\right)$ & $\beta_{2}\left(D P R E^{*} X_{t}\right)$ & $B_{1}\left(X_{t}\right)$ & $B_{2}\left(D P R E^{*} X_{t}\right)$ & $\beta_{1}\left(X_{t}\right)$ & $\beta_{2}\left(D P R E^{*} X_{t}\right)$ & $\beta_{1}\left(X_{t}\right)$ & $B_{2}\left(D P R E^{*} X_{t}\right)$ & $B_{1}\left(X_{t}\right)$ & $\beta_{2}\left(D_{\left.P R E^{*} X_{t}\right)}\right.$ \\
\hline LNDEBTGDP $_{t}$ & $0.916^{* *}$ & $1.638^{* *}$ & $-1.517^{* *}$ & $\cdot$ & $0.533^{* *}$ & $5.500^{\circ *}$ & - & - & $\cdot$ & $\cdot$ & $-2.373^{* *}$ & $5.703^{* *}$ & $0.500^{* *}$ & $-0.298^{* *}$ & $-1.283^{* *}$ & $1.011^{* *}$ & $-2.071^{* *}$ & $5.689^{* *}$ \\
\hline & $(0.132)$ & $(0.646)$ & $(0.324)$ & & $(0.115)$ & $(2.260)$ & & & & & $(0.165)$ & $(0.665)$ & $(0.115)$ & $(0.117)$ & $(0.189)$ & $(0.239)$ & $(0.251)$ & $(0.689)$ \\
\hline ONOFFDIF $_{t}$ & $\begin{array}{l}-2.141^{* * *} \\
(0.432)\end{array}$ & $\begin{array}{l}3.744^{* *} \\
(0.566)\end{array}$ & $\begin{array}{r}-1.365^{* *} \\
(0.577)\end{array}$ & $\begin{array}{c}-2.290^{* *} \\
(0.971)\end{array}$ & $\begin{array}{c}-1.631^{* *} \\
(0.247)\end{array}$ & $\begin{array}{l}4.524^{4 *} \\
(0.924)\end{array}$ & $\begin{array}{l}-1.271^{* *} \\
(0.417)\end{array}$ & $\begin{array}{l}4.018^{* *} \\
(1.062)\end{array}$ & - & - & $\begin{array}{c}-1.358^{* * *} \\
(0.390)\end{array}$ & $\begin{array}{l}1.913^{* *} \\
(0.545)\end{array}$ & $\cdot$ & - & - & $\begin{array}{l}1.594^{* *} \\
(0.284)\end{array}$ & - & - \\
\hline ONOFFDIF $2_{t}$ & $\begin{array}{l}17.615^{* *} \\
(4.855)\end{array}$ & $\begin{array}{c}-15.591^{*} \\
(8.433)\end{array}$ & - & $\begin{array}{l}18.141^{\star *} \\
(7.735)\end{array}$ & $\begin{array}{l}10.813^{* *} \\
(1.750)\end{array}$ & $\begin{array}{c}-17.480^{* *} \\
(2.934)\end{array}$ & $\begin{array}{l}23.925^{* *} \\
(6.518)\end{array}$ & 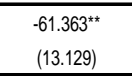 & $\begin{array}{l}4.766^{*+*} \\
(2.171)\end{array}$ & - & - & - & - & - & - & $\begin{array}{l}-7.161^{* *} \\
(1.797)\end{array}$ & $\begin{array}{l}11.072^{* *} \\
(3.385)\end{array}$ & $\begin{array}{c}-17.219^{* *} \\
(5.609)\end{array}$ \\
\hline BIDASKDIF $_{t}$ & $\begin{array}{l}0.399^{* *} \\
(0.186) \\
\end{array}$ & \begin{tabular}{|l|l}
$4.733^{* *}$ \\
$(1.080)$ \\
\end{tabular} & $\begin{array}{r}-0.320^{* *} \\
(0.134) \\
\end{array}$ & \begin{tabular}{|c|}
$-3.901^{* *}$ \\
$(0.914)$ \\
\end{tabular} & $\cdot$ & $\cdot$ & $\begin{array}{l}-0.578^{* *} \\
(0.189) \\
\end{array}$ & $\begin{array}{l}4.019^{\text {t* }} \\
(1.535) \\
\end{array}$ & $\cdot$ & - & - & - & - & $\begin{array}{r}-1.344^{* *} \\
(0.239) \\
\end{array}$ & - & $\begin{array}{l}-0.348^{*} \\
(0.180) \\
\end{array}$ & $\cdot$ & $\begin{array}{l}1.236^{*} \\
(0.754) \\
\end{array}$ \\
\hline BIDASKDIF $2_{t}$ & $\begin{array}{r}-2.041^{* *} \\
(0.948)\end{array}$ & $\begin{array}{l}-93.305^{* *} \\
(30.215)\end{array}$ & $\cdot$ & $\begin{array}{l}84.921^{* *} \\
(32.750)\end{array}$ & & - & - & $\begin{array}{l}146.486^{6 *} \\
(72.806)\end{array}$ & $\begin{array}{l}191.559^{* *} \\
(95.043)\end{array}$ & $\begin{array}{l}-281.101^{1 *} \\
(115.133)\end{array}$ & $\begin{array}{c}10.017^{* *} \\
(4.474)\end{array}$ & $\begin{array}{c}-11.053^{3 *} \\
(4.959)\end{array}$ & & $\begin{array}{l}6.816^{*} \\
(3.807)\end{array}$ & $\begin{array}{l}6.043^{3 *} \\
(1.015)\end{array}$ & - & $\begin{array}{r}17.571^{* * *} \\
(2.972)\end{array}$ & \\
\hline$U_{\text {USSPREAD }}$ & $\cdot$ & $\cdot$ & - & $\cdot$ & $\begin{array}{l}-0.051^{* *} \\
(0.018)\end{array}$ & $\begin{array}{l}1.262^{* *} \\
(0.249)\end{array}$ & - & $\begin{array}{l}0.629^{* *} \\
(0.211)\end{array}$ & $\cdot$ & $\begin{array}{l}-0.450^{* *} \\
(0.227)\end{array}$ & $\begin{array}{l}-1.735^{* *} \\
(0.149)\end{array}$ & $\begin{array}{l}4.359^{* *} \\
(1.265)\end{array}$ & $\begin{array}{l}-0.659^{* *} \\
(0.162)\end{array}$ & $\begin{array}{l}0.220^{* *} \\
(0.032)\end{array}$ & - & $\begin{array}{l}0.395^{* *} \\
(0.026)\end{array}$ & $\begin{array}{l}-0.395^{* *} \\
(0.056)\end{array}$ & $\begin{array}{l}2.494^{* *} \\
(0.344)\end{array}$ \\
\hline LNDEBTGDP*USSPREAD $D_{t}$ & $\begin{array}{l}-0.533^{* *} \\
(0.155) \\
\end{array}$ & $\begin{array}{l}-2.56^{+* *} \\
(1.222) \\
\end{array}$ & - & - & $\begin{array}{l}-0.525^{* *} \\
(0.156) \\
\end{array}$ & $\begin{array}{l}-9.975^{\text {t* }} \\
(4.363) \\
\end{array}$ & - & - & - & $\cdot$ & $\begin{array}{l}2.079^{* *} \\
(0.170) \\
\end{array}$ & $\begin{array}{l}-4.394^{* *} \\
(1.270) \\
\end{array}$ & $\cdot$ & \begin{tabular}{|l|}
$-0.613^{\text {t*x }}$ \\
$(1.133)$ \\
\end{tabular} & $\begin{array}{l}3.695{ }^{* *} \\
(0.277) \\
\end{array}$ & $\begin{array}{l}-2.920^{* *} \\
(0.373) \\
\end{array}$ & $\begin{array}{l}2.307^{* *} \\
(0.276) \\
\end{array}$ & \begin{tabular}{|l|}
$-9.159^{\text {t* }}$ \\
$(1.154)$ \\
\end{tabular} \\
\hline ONOFFDIF"USSPREAD $D_{t}$ & $\begin{array}{l}2.181^{* *} \\
(0.648) \\
\end{array}$ & $\begin{array}{l}-4.813^{* *} \\
(0.957) \\
\end{array}$ & - & $\begin{array}{l}4.377^{* *} \\
(1.475) \\
\end{array}$ & $\begin{array}{l}1.815^{* *} \\
(0.312) \\
\end{array}$ & $\begin{array}{l}-7.608^{* *} \\
(1.542) \\
\end{array}$ & - & $\begin{array}{l}-4.412^{+*} \\
(1.604) \\
\end{array}$ & $\begin{array}{l}1.413^{*+} \\
(0.619) \\
\end{array}$ & - & $\begin{array}{l}1.773^{* \star} \\
(0.663) \\
\end{array}$ & & - & - & $\begin{array}{l}-2.938^{* *+} \\
(0.493) \\
\end{array}$ & - & - & $\begin{array}{l}1.561^{*} \\
(0.863) \\
\end{array}$ \\
\hline ONOFFDIF²USSPREAD & $\begin{array}{c}-22.792^{* *} \\
(7.524)\end{array}$ & - & - & $\begin{array}{l}-31.968^{* *} \\
(10.655)\end{array}$ & $\begin{array}{c}-12.218^{* *} \\
(2.041)\end{array}$ & $\begin{array}{l}27.089 * \\
(4.846)\end{array}$ & $\begin{array}{c}-26.900^{* *} \\
(9.914)\end{array}$ & $\begin{array}{l}95.507^{* *} \\
(21.334)\end{array}$ & $\begin{array}{c}-11.707^{* *} \\
(3.366)\end{array}$ & - & - & $\begin{array}{l}24.480^{*} \\
(12.518)^{2}\end{array}$ & - & - & - & $\begin{array}{c}12.511^{* *} \\
(2.087)\end{array}$ & $\begin{array}{c}-13.033^{* *} \\
(5.661)\end{array}$ & $\begin{array}{c}21.534^{* *} \\
(8.477)\end{array}$ \\
\hline BIDASKDIF'USSPREAD ${ }_{t}$ & & \begin{tabular}{|c|}
$-9.074^{* *}$ \\
$(2.057)$ \\
\end{tabular} & $\begin{array}{l}0.534^{* *} \\
(0.126) \\
\end{array}$ & $\begin{array}{l}8.753^{* *} \\
(1.590) \\
\end{array}$ & & $\begin{array}{c}-17.471^{* *} \\
(7.304) \\
\end{array}$ & & $\begin{array}{l}-6.193^{* *+} \\
(2.962) \\
\end{array}$ & $\begin{array}{l}11.310^{*} \\
(6.047) \\
\end{array}$ & - & - & 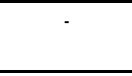 & & $\begin{array}{l}1.2911^{* *} \\
(0.321) \\
\end{array}$ & $\begin{array}{l}1.055^{*} \\
(0.279) \\
\end{array}$ & - & $\begin{array}{l}-0.296^{*} \\
(0.165) \\
\end{array}$ & \\
\hline BIDASKDIF2 USSPREAD $_{t}$ & & $\begin{array}{l}207.74^{* * *} \\
(58.660)\end{array}$ & - & $\begin{array}{c}-140.377^{* *} \\
(60.130)\end{array}$ & & $\begin{array}{l}69.629^{*} \\
(37.129)\end{array}$ & $\begin{array}{c}-14.353^{*} \\
(8.074)\end{array}$ & $\begin{array}{c}-256.990^{*} \\
(144.199)\end{array}$ & $\begin{array}{l}-326.538^{* *} \\
(152.508)\end{array}$ & $\begin{array}{l}503.828^{* *} \\
(202.4111)\end{array}$ & $\begin{array}{c}-17.142^{* *} \\
(4.646)\end{array}$ & $\begin{array}{c}20.207^{* *} \\
(6.013) \\
\end{array}$ & - & & - & $\begin{array}{l}-7.152^{* *} \\
(1.548)\end{array}$ & $\begin{array}{c}-26.030^{* *} \\
(5.093)\end{array}$ & \\
\hline & $\gamma$ & & $\gamma$ & & $\gamma$ & & $\gamma$ & & $\gamma$ & & $\gamma$ & & $\gamma$ & & $\gamma$ & & $\gamma$ & \\
\hline DPRE & - & & - & & $\begin{array}{l}-0.619^{* * *} \\
(0.136)\end{array}$ & & $\begin{array}{l}-0.299 \\
(0.142)\end{array}$ & & - & & $\begin{array}{l}-5.576^{*+*} \\
(0.663)\end{array}$ & & - & & - & & $\begin{array}{r}-1.590^{* * *} \\
(0.201)\end{array}$ & \\
\hline & $\alpha$ & & $\alpha$ & & $\alpha$ & & $\alpha$ & & $\alpha$ & & $\alpha$ & & $\alpha$ & & $\alpha$ & & $\alpha$ & \\
\hline CONSTANT & $\begin{array}{l}0.194^{* *} \\
(0.022)\end{array}$ & & $\begin{array}{l}1.782^{* *} \\
(0.300)\end{array}$ & & $\begin{array}{l}0.267 * \\
(0.012)\end{array}$ & & & & - & & $\begin{array}{l}2.361^{* *} \\
(0.146)\end{array}$ & & $\begin{array}{l}0.744^{* *} \\
(0.141)\end{array}$ & & $\begin{array}{l}0.134^{* *} \\
(0.022)\end{array}$ & & $\begin{array}{l}0.655^{* *} \\
(0.054)\end{array}$ & \\
\hline $\begin{array}{l}\text { Number of obs } \\
F= \\
\text { Prob }>F=\end{array}$ & $\begin{array}{c}1481 \\
F(23,1457)= \\
0.00\end{array}$ & & $\begin{array}{c}1492 \\
F(23,1468)= \\
0.00\end{array}$ & 429.29 & $\begin{array}{c}310 \\
F(23,1286)= \\
0.00\end{array}$ & & $\begin{array}{l}1478 \\
F(23,145 \\
0.00\end{array}$ & $=107.29$ & $\begin{array}{c}582 \\
F(23,558)= \\
0.00\end{array}$ & 75.52 & $\begin{array}{c}1489 \\
F(23,1465) \\
0.00\end{array}$ & $=308.20$ & $\begin{array}{l}1490 \\
F(22,1 \\
0.00\end{array}$ & 7) = 364.47 & $\begin{array}{c}1323 \\
F(13,130 \\
0.00\end{array}$ & $=143.58$ & $\begin{array}{c}1494 \\
F(23,1470) \\
0.00\end{array}$ & $=148.17$ \\
\hline
\end{tabular}

$* *$ Significant at 5 percent confidence level

* Significant at 10 percent confidence level.

Standard Errorss within parentheses 
TABLE 7

\begin{tabular}{|c|c|c|c|c|c|c|c|c|c|c|}
\hline \multicolumn{11}{|c|}{\begin{tabular}{|l} 
SPECIFICATION IV(DYNAMIC MODEL) \\
Regression with Newey-West Standard Errors \\
Sample: Pre-EMU: 1996:01-1998:12 \\
EMU: 1999:01-2001:12 \\
dependent variable: ASPREAD
\end{tabular}} \\
\hline \multirow[b]{2}{*}{$X_{t}$} & AUSTRIA & BELGIUM & FINLAND & FRANCE & \begin{tabular}{l|l|} 
IRELAND \\
\end{tabular} & ITALY & THE NETHERLANDS & PORTUGAL & \multicolumn{2}{|c|}{ SPAIN } \\
\hline & $B_{1}\left(X_{t}\right) \quad B_{2}\left(D P R E^{*} X_{t}\right)$ & $B_{B_{1}\left(X_{t}\right)} \quad B_{2}\left(D P R E^{*} X_{t}\right)$ & $\begin{array}{lll}B_{1}\left(X_{t}\right) & B_{2}\left(D P R E^{*} X_{t}\right)\end{array}$ & $B_{1}\left(X_{t}\right) \quad B_{2}\left(\operatorname{DPRE}^{*} X_{t}\right)$ & $\overline{B_{1}\left(X_{t}\right)} \quad B_{2}\left(D P R E^{*} X_{t}\right)$ & 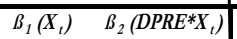 & $B_{1}\left(X_{t}\right) \quad B_{2}\left(D^{\prime} P E^{*} X_{t}\right)$ & $\begin{array}{ll}B_{1}\left(X_{t}\right) & B_{2}\left(D P R E^{*} X_{t}\right)\end{array}$ & $\overline{B_{1}\left(X_{t}\right)}$ & $\overline{B_{2}\left(D P R E^{*} X_{t}\right)}$ \\
\hline$\overline{A S P R E A D_{t-1}}$ & $\begin{array}{l}0.732^{* *} \\
(0.038)\end{array}$ & $\begin{array}{|ll|}0.749^{* *} & -0.109^{*} \\
(0.031) & (0.059) \\
\end{array}$ & $\begin{array}{|ll|}0.50^{\text {1*+ }} & 0.170^{*+*} \\
(0.041) & (0.059) \\
\end{array}$ & \begin{tabular}{ll|}
$0.476^{* *}$ & $0.152^{* *}$ \\
$(0.043)$ & $(0.055)$ \\
\end{tabular} & $\begin{array}{l}0.596^{*+} \\
(0.078)\end{array}$ & \begin{tabular}{ll|}
$0.899^{* *}$ & $-0.130^{* *}$ \\
$(0.039)$ & $(0.050)$ \\
\end{tabular} & \begin{tabular}{ll|}
$0.218^{* *}$ & $0.279^{* *}$ \\
$(0.038)$ & $(0.057)$ \\
\end{tabular} & $\begin{array}{|ll|}0.628^{* *} & 0.175^{* *} \\
(0.036) & (0.044) \\
\end{array}$ & $\begin{array}{l}0.629^{*+*} \\
(0.055)\end{array}$ & $\begin{array}{l}-0.175^{* *} \\
(0.070)\end{array}$ \\
\hline LNDEBTGDP $_{t}$ & $\begin{array}{ll}0.213^{* *} & 0.822^{* *} \\
(0.095) & (0.413) \\
\end{array}$ & - & $\begin{array}{l}0.322^{2 *+} \\
(0.095)\end{array}$ & 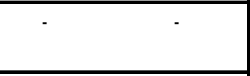 & . & $\begin{array}{l}-0.240^{* *} \\
(0.107) \\
\end{array}$ & \begin{tabular}{ll|}
$0.396^{* *}$ & $-0.259^{* *}$ \\
$(0.113)$ & $(0.108)$ \\
\end{tabular} & - & $\begin{array}{l}-0.844^{* *} \\
(0.224) \\
\end{array}$ & $\begin{array}{l}2.831^{* *} \\
(0.619) \\
\end{array}$ \\
\hline ONOFFDIF $_{t}$ & $\begin{array}{l}0.955^{* *} \\
(0.412)\end{array}$ & - & $\begin{array}{ll}-0.899^{* *} & 2.130^{* *} \\
(0.201) & (0.737)\end{array}$ & - & - & - & $\cdot$ & $\begin{array}{l}0.305^{*} \\
(0.170)\end{array}$ & $\cdot$ & $\cdot$ \\
\hline ONOFFDIF ${ }_{t}$ & $\cdot$ & - & $\begin{array}{ll}6.024^{* *} & -8.948^{* *} \\
(1.346) & (2.481)\end{array}$ & $\begin{array}{c}-30.873^{* *} \\
(11.811) \\
\end{array}$ & $\begin{array}{l}2.746^{*} \\
(1.650)\end{array}$ & - & - & $\begin{array}{l}-1.599^{*} \\
(0.856)\end{array}$ & - & $\begin{array}{l}-8.681^{*} \\
(5.320)\end{array}$ \\
\hline BIDASKDIF $_{t}$ & $\begin{array}{ll}0.214^{*} & 2.731^{* *} \\
(0.122) & (0.669)\end{array}$ & $\begin{array}{l}-1.627^{* *} \\
(0.729)\end{array}$ & . & - & . & - & $\begin{array}{l}-0.802^{* *} \\
(0.224)\end{array}$ & . & - & - \\
\hline BIDASKDIF $_{t}$ & \begin{tabular}{ll|}
$-1.232^{* *}$ & $-62.528^{* *}$ \\
$(0.590)$ & $(17.012)$ \\
\end{tabular} & - & - & - & - & - & - & $\begin{array}{l}1.461^{* *} \\
(0.699) \\
\end{array}$ & $\begin{array}{l}7.945^{* *} \\
(2.114) \\
\end{array}$ & \\
\hline$U_{\text {USSPREAD }}$ & $\begin{array}{l}-0.117^{* *} \\
(0.059) \\
\end{array}$ & - & $\begin{array}{l}-0.030^{*} \\
(0.016) \\
\end{array}$ & - & - & $\begin{array}{l}-0.201^{* *} \\
(0.101) \\
\end{array}$ & $\begin{array}{ll}-0.525^{* *} & 0.122^{* *} \\
(0.158) & (0.035) \\
\end{array}$ & $\begin{array}{l}-2.310^{*} \\
(1.296) \\
\end{array}$ & $\begin{array}{l}-0.170^{* *} \\
(0.052) \\
\end{array}$ & $\begin{array}{l}1.312^{*+*} \\
(0.309) \\
\end{array}$ \\
\hline LNDEBTGDP*USSPREAD $_{t}$ & $\begin{array}{l}-1.343^{*} \\
(0.773)\end{array}$ & - & $\begin{array}{l}-0.334^{4 *} \\
(0.129)\end{array}$ & - & . & $\begin{array}{l}0.237^{* *} \\
(0.120)\end{array}$ & $\begin{array}{l}-0.478^{* *} \\
(0.123)\end{array}$ & $\begin{array}{l}-0.665^{* *} \\
(0.186)\end{array}$ & $\begin{array}{l}0.984^{* *} \\
(0.265)\end{array}$ & $\begin{array}{l}-4.716^{* *} \\
(1.055)\end{array}$ \\
\hline ONOFFDIF"USSPREAD & $\begin{array}{l}-1.134^{*} \\
(0.664)^{2}\end{array}$ & - & $\begin{array}{l}1.007^{* *} \\
(0.268)\end{array}$ & $\cdot$ & $\begin{array}{l}0.979^{* * *} \\
(0.433)\end{array}$ & . & - & $\begin{array}{l}-0.702^{* *} \\
(0.289)\end{array}$ & - & - \\
\hline${\text { ONOFFDIF } 2^{2} U S S P R E A D_{t}}$ & - & - & \begin{tabular}{ll|}
$-6.907^{* *}$ & $12.753^{* *}$ \\
$(1.740)$ & $(4.281)$ \\
\end{tabular} & $\begin{array}{l}46.825^{* *} \\
(19.356) \\
\end{array}$ & $\begin{array}{l}-5.651^{* *} \\
(2.518) \\
\end{array}$ & - & - & $\begin{array}{l}2.642^{*} \\
(1.404) \\
\end{array}$ & - & - \\
\hline BIDASKDIF $^{*} U S S P R E A D_{t}$ & $\begin{array}{ll}- & -5.292^{* *} \\
& (1.242) \\
\end{array}$ & $\begin{array}{l}3.577^{* *} \\
(1.290) \\
\end{array}$ & - & $\cdot$ & $\bar{\cdot}$ & - & $\begin{array}{l}0.802^{* *} \\
(0.296) \\
\end{array}$ & $\cdot$ & - & - \\
\hline BIDASKDIF2 USSPREAD $_{t}$ & $\begin{array}{ll}-1.187^{* *} & 130.936^{* *} \\
(0.593) & (31.780)\end{array}$ & 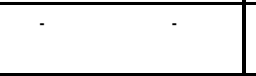 & - & 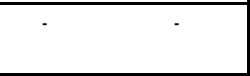 & - & - & - & - & $\begin{array}{r}-12.014^{* *} \\
(3.426)\end{array}$ & \\
\hline & $\gamma$ & $\gamma$ & $\gamma$ & $\gamma$ & $\gamma$ & $\gamma$ & $\gamma$ & $\gamma$ & $\gamma$ & \\
\hline DPRE & & & $\begin{array}{l}-0.191^{* *} \\
(0.092)\end{array}$ & & 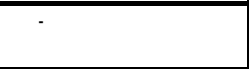 & $\begin{array}{l}-0.934^{*} \\
(0.501)\end{array}$ & & & $\begin{array}{l}-0.771^{* *} \\
(0.179)\end{array}$ & \\
\hline & $\alpha$ & $\alpha$ & $\alpha$ & $\alpha$ & $\alpha$ & $\alpha$ & $\alpha$ & $\alpha$ & $\alpha$ & \\
\hline CONSTANT & $\begin{array}{l}0.053^{3 * *} \\
(0.014)\end{array}$ & $\begin{array}{l}0.382^{2+*} \\
(0.195)\end{array}$ & $\begin{array}{l}0.137^{* *} \\
(0.014)\end{array}$ & & & $\begin{array}{l}0.241^{+*} \\
(0.102)\end{array}$ & $\begin{array}{l}0.587^{7 *} \\
(0.139) \\
\end{array}$ & $\begin{array}{l}0.096^{*+*} \\
(0.021)\end{array}$ & $\begin{array}{l}0.257^{* *} \\
(0.054)\end{array}$ & \\
\hline $\begin{array}{l}\text { Number of obs } \\
F= \\
\text { Prob }>F=\end{array}$ & $\begin{array}{c}1480 \\
F(25,1454)=1192.72 \\
0.00\end{array}$ & $\begin{array}{l}1491 \\
F(25,1465)=856.03 \\
0.00\end{array}$ & $\begin{array}{c}1310 \\
F(25,1284)=325.44 \\
0.00\end{array}$ & $\begin{array}{c}1477 \\
F(25,1451)=162.39 \\
0.00\end{array}$ & $\begin{array}{l}582 \\
F(23,556)=104.97 \\
0.00\end{array}$ & $\begin{array}{l}1488 \\
F(25,1462)=1005.23 \\
0.00\end{array}$ & $\begin{array}{l}1489 \\
F(24,1464)=364.08 \\
0.00\end{array}$ & $\begin{array}{c}1322 \\
F(15,1305)=417.74 \\
0.00\end{array}$ & $\begin{array}{c}1493 \\
F(25,1467) \\
0.00\end{array}$ & $=256.96$ \\
\hline
\end{tabular}

*rob $>F=0.00$

(n)

Standard Errors within parentheses 